Article

\title{
Synthesis of Porphyrin-Dendrimers with a Pyrene in the Periphery and Their Cubic Nonlinear Optical Properties
}

\author{
Eric G. Morales-Espinoza ${ }^{1}$, Irina V. Lijanova ${ }^{2}$, Omar G. Morales-Saavedra ${ }^{3}$, \\ Vícente Torres-Zuñiga ${ }^{3}$, Simon Hernandez-Ortega ${ }^{1}$ and Marcos Martínez-García ${ }^{1, *}$ \\ 1 Instituto de Química, Universidad Nacional Autónoma de México, Cd. Universitaria, \\ Circuito Exterior, Coyoacán, C.P., México D.F. 04510, Mexico \\ 2 Instituto Politécnico Nacional, CIITEC, Cerrada Cecati S/N, Colonia Santa Catarina de \\ Azcapotzalco, C.P., México D.F. 02250, Mexico \\ 3 Centro de Ciencias Aplicadas y Desarrollo Tecnológico, Universidad Nacional Autónoma de \\ México, CCADET-UNAM, Circuito exterior S/N, Ciudad Universitaria C.P., \\ México D.F. 04510, Mexico
}

* Author to whom correspondence should be addressed: E-Mail: margar@servidor.unam.mx.

Received: 9 June 2011; in revised form: 3 August 2011 / Accepted: 5 August 2011 /

Published: 15 August 2011

\begin{abstract}
Dendrons of pyrene derivatives were attached to a porphyrin core. A marked effect in solution for the dendrimers was observed in the absorption spectra. All the compounds obtained were characterized by ${ }^{1} \mathrm{H}-,{ }^{13} \mathrm{C}-\mathrm{NMR}$, FTIR, UV-vis, MALDI-TOF or $\mathrm{FAB}+$ mass spectrometry and elemental analysis. The cubic nonlinear optical behavior of some the synthesized compounds was tested via Z-Scan measurements in spin-coated film samples.
\end{abstract}

Keywords: pyrene; porphyrin; dendrimers; nonlinear optics

\section{Introduction}

Dendrimers are highly branched polymers with a well defined structure, uniform size and molecular weight [1-8]. They are composed by a multifunctional central core to which dendritic branches are connected [9-13]. According to their shape, dendrimers are divided into two types. The first one has a circular or elliptic shape in which repeat units are regularly stretched from a core [14,15], and the second type has a conic shape with repeated units directionally stretched from a core [16-18]. Since it 
is possible to control the dendrimer's size and structure, and at the same time introduce different kinds of functional groups into their terminal groups or core, numerous applications for these molecules have been found in different fields such as catalysis [19-22], biomedicine, energy or charge-transfer systems [23-27], sensors [28], charge transfer of light-emitting layer in organic light emitting diodes (OLEDs) [29-31], etc. In addition to the above advantages, dendrimers manifest a highly ordered structure and produce thin films with various functional groups on the top surface of the substrate, making possible the creation of unique materials in which surface characteristics are controlled at a molecular level. In the present work we report the synthesis of two generations of dendrimers with molecules of pyrene on the periphery and a tetraphenylporphyrin core.

\section{Results and Discussion}

The synthesis of the two pyrene-derivative dendrimer series was carried out applying a convergent pathway that consists of two steps, the first one being the synthesis of the two dendrons, and the second one the $O$-alkylation of the dendrons to the porphyrin. Following this order, dendrons containing pyrenebenzyloxy- and pyrene-1-methyl-3-chloropropoxybenzyloxy groups were prepared according to the convergent Fréchet approach [32] starting from a reduction reaction from the commercially available 1-pyrenecarboxaldehyde $\mathbf{1}$ via the reduction of the aldehyde $\mathbf{1}$ to obtain the pyren-1-ylmethanol 2 and its chlorination with $\mathrm{SOCl}_{2}$ and pyridine to obtain compound $\mathbf{3}$ (Scheme 1) or its $O$-alkylation with 1-bromo-3-chloropropane in acetone and $\mathrm{K}_{2} \mathrm{CO}_{3}$ at reflux to obtain the compound 4 (Scheme 1).

Scheme 1. Synthesis of the pyrene derivatives.

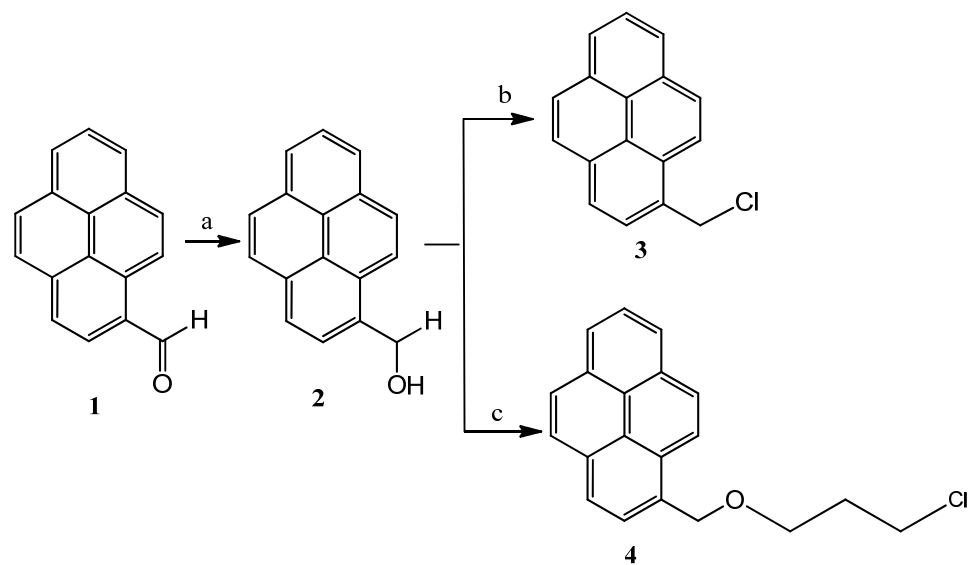

Reagents and Conditions: (a) $\mathrm{LiAlH}_{4}, \mathrm{THF}, 0{ }^{\circ} \mathrm{C}, \mathrm{N}_{2}$; (b) $\mathrm{SOCl}_{2}$, pyridine, $\mathrm{CH}_{2} \mathrm{Cl}_{2}$; and (c) $\mathrm{Br}\left(\mathrm{CH}_{2}\right)_{3} \mathrm{Cl}, \mathrm{K}_{2} \mathrm{CO}_{3}$, acetone, reflux.

The following signals were observed in the ${ }^{1} \mathrm{H}-\mathrm{NMR}$ spectrum of compound 2: one singlet at $\delta_{\mathrm{H}}$ 1.83 for the $\mathrm{OH}$ proton, one singlet at $\delta_{\mathrm{H}} 5.36$ due to the $\mathrm{CH}_{2}$ group and for the pyrene group (multiplets at $\delta_{\mathrm{H}}$ 7.96-8.34). The structure of the pyren-1-ylmethanol compound 2 was confirmed by $\mathrm{X}$-ray diffraction studies (Figure 1). In the crystal structure, a hydrogen bridge was observed between two pyren-1-ylmethanol moieties and the crystal packing of compound $\mathbf{2}$ showed strong interactions between the four pyrene molecules. 
Figure 1. Crystal structure and crystal packing of the 1-(chloromethyl)pyrene 2. Selected bond lengths $[\AA]$ : $\mathrm{O}(1)-\mathrm{C}(21)=1.421, \mathrm{C}(21)-\mathrm{C}(1)=1.508, \mathrm{C}(1)-\mathrm{C}(2)=1.378$. Selected angles $\left({ }^{\circ}\right)$ : $\mathrm{O}(1)-\mathrm{C}(21)-\mathrm{C}(1)=114.2, \mathrm{C}(21)-\mathrm{C}(1)-\mathrm{C}(2)=120.2, \mathrm{C}(1)-\mathrm{C}(2)-\mathrm{C}(3)=121.9$.
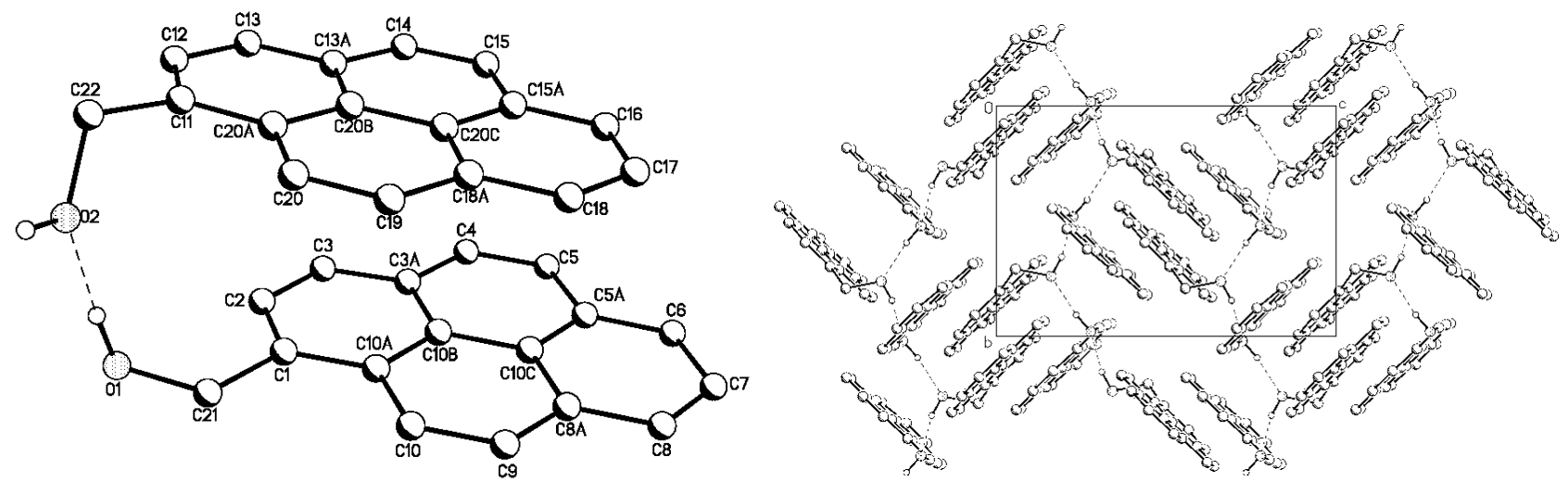

The chemical structure of the 1-(chloromethyl)pyrene 3 was confirmed by ${ }^{13} \mathrm{C}$-NMR spectroscopy. In the spectrum, the most significant resonance signals were those observed at $\delta \mathrm{c} 44.77$ of the $\mathrm{CH}_{2}-\mathrm{Cl}$ group, and the aromatic signals due to the pyrene carbons.

In the ${ }^{1} \mathrm{H}-\mathrm{NMR}$ spectrum of compound 4 , the following signals were observed: one multiplet at $\delta$ 2.03 due to the $\mathrm{CH}_{2}$ group, two multiplets at $\delta 3.63$ and at $\delta 4.09$ assigned to the $\mathrm{CH}_{2}-\mathrm{Cl}$ and $\mathrm{CH}_{2}-\mathrm{O}$ groups with a coupling constants $J=6.4$ and $J=1.6 \mathrm{~Hz}$, respectively. One singlet at $\delta 5.12$ due to the $\mathrm{CH}_{2}-\mathrm{O}$ joined to the pyrene, and finally the characteristic signals due to the pyrene moiety. The structure of the compound 4 was further confirmed by mass spectrometry.

Chlorides 3 and $\mathbf{4}$ were attached to the 3,5-dihydroxybencyl alcohol 5 in DMF, cesium carbonate at $60{ }^{\circ} \mathrm{C}$ to give alcohol intermediates 6,7 , which were converted into chlorides 8 and 9 upon treatment with thionyl chloride and pyridine in dichloromethane (Scheme 2). Dendrons 8 and 9 are the first generation dendrons of the pyrene derivative families.

Scheme 2. Synthesis of dendrons 8,9 and 12, 13 .

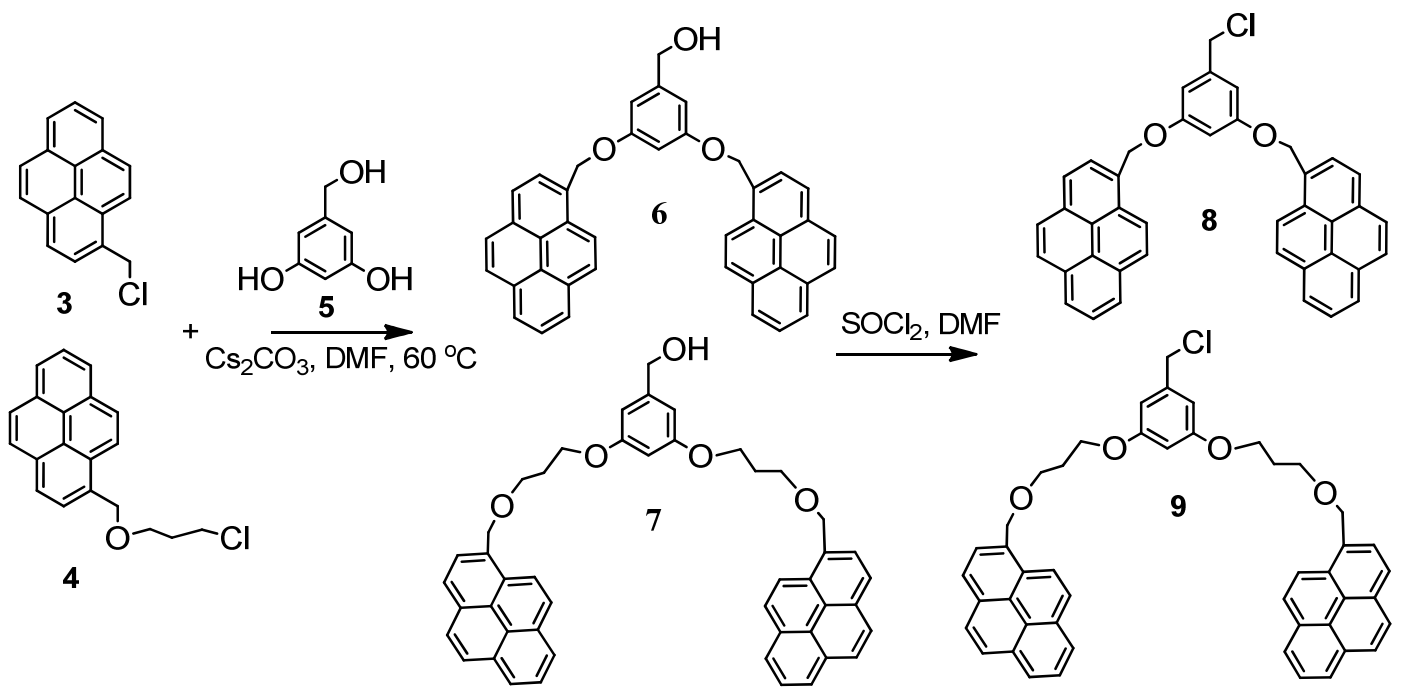



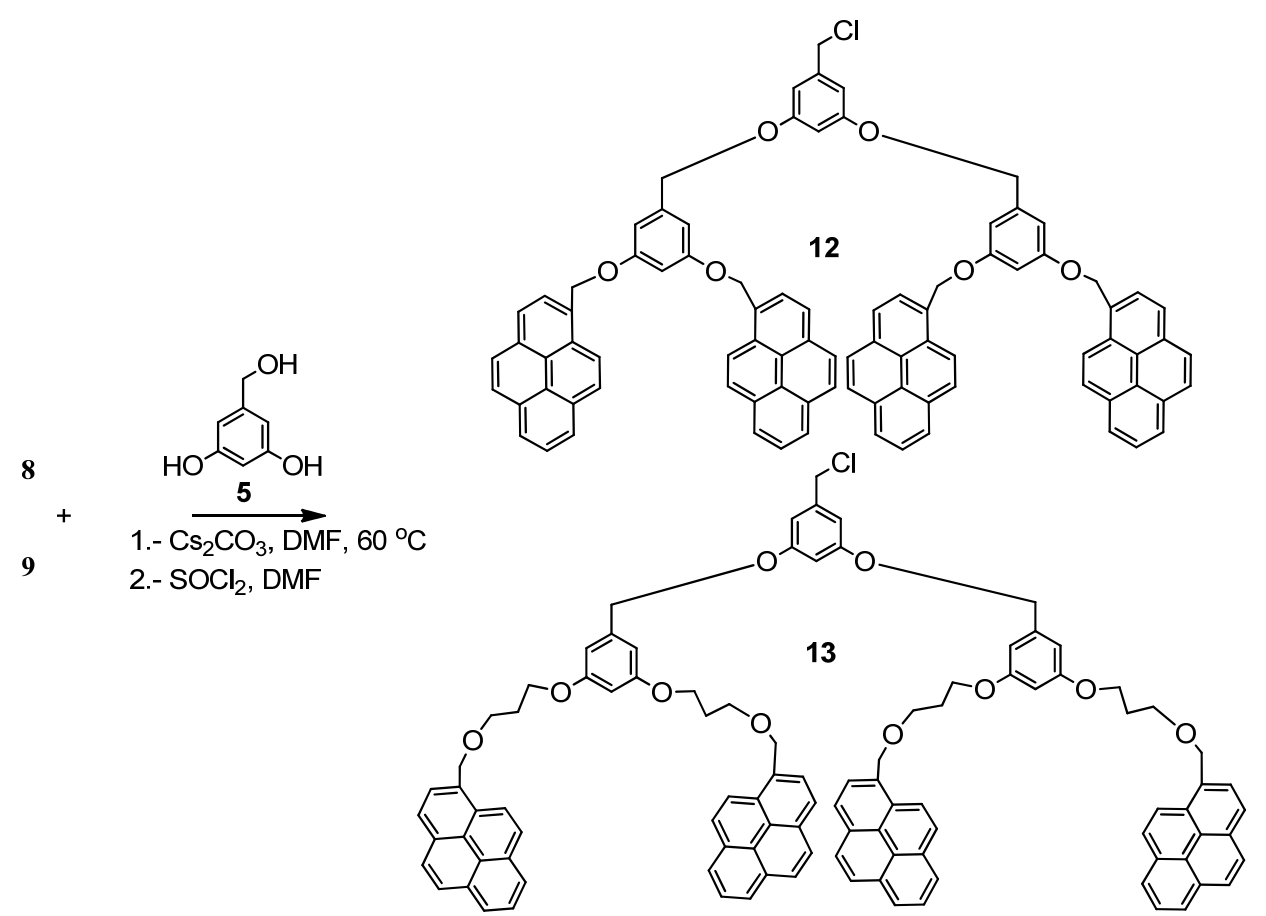

The second generation dendrons 12 and $\mathbf{1 3}$ were obtained from the dendrons 8 and $\mathbf{9}$ following the same methodology. First they were attached to 3,5-dihydroxybenzyl alcohol (5) in DMF using cesium carbonate at $60{ }^{\circ} \mathrm{C}$ to give alcohols 10, 11, which were converted into chlorides 12 and 13 upon treatment with thionyl chloride and pyridine in dichloromethane. Dendrons $\mathbf{1 2}$ and $\mathbf{1 3}$ are the second generation dendrons of the pyrene derivatives families.

The structures of 12 and $\mathbf{1 3}$ was confirmed by ${ }^{1} \mathrm{H}-\mathrm{NMR}$ spectroscopy. Signals at $\delta_{\mathrm{H}} 4.60,5.76$ (dendron 12) and $\delta_{\mathrm{H}} 4.35,5.15$ (dendron 13) corresponded to the methylene protons $\mathrm{Ar}-\mathrm{CH}_{2}-\mathrm{Cl}$ and Pyrene- $\mathrm{CH}_{2}-\mathrm{O}$. Compound 13 showed three signals at $\delta_{\mathrm{H}} 2.03,3.73$ and 4.59 due to the propyloxy groups. The aromatic protons were observed as one singlet at $\delta_{\mathrm{H}} 6.84$ and 6.80, for compound 12 and 13, respectively. The characteristic signals for the pyrene moiety also were observed.

The synthesis of the dendrimers is depicted in Scheme 3. This synthesis involves only one step, an O-alkylation between dendrons 8,12 or 9, 13 and porphyrin 14. The reaction was carried out in dimetylformamide and $\mathrm{Cs}_{2} \mathrm{CO}_{3}$ at $60^{\circ} \mathrm{C}$ for 3 days and the dendrimers were obtained in good yields.

The ${ }^{1} \mathrm{H}-\mathrm{NMR}$ spectra of the dendrimers $\mathbf{1 5}$ and $\mathbf{1 6}$ (Figure 2) showed one broad signal at $\delta_{\mathrm{H}}-2.23$ due to the N-H protons, three multiplets at $\delta_{\mathrm{H}} 2.17,3.57$ and 3.97 assigned to the $\mathrm{CH}_{2}$ protons of the propyl group, two singlets at $\delta_{\mathrm{H}} 4.77$ and $\delta_{\mathrm{H}} 4.98$ due to the $\mathrm{Ar}-\mathrm{CH}_{2}-\mathrm{O}$ and $\mathrm{Pyrene}-\mathrm{CH}_{2}-\mathrm{O}$. The aromatic protons at the dendron were observed as two broad signals at $\delta_{\mathrm{H}} 6.25$ and $\delta_{\mathrm{H}} 6.36$. The characteristic signals for the pyrene moiety at $\delta_{\mathrm{H}} 7.74$ to $\delta_{\mathrm{H}} 8.02$ were also observed. Two doublets at $\delta_{\mathrm{H}} 7.56$ and 8.07 were assigned to the aromatic protons with a coupling constant of $J=8.2 \mathrm{~Hz}$ joined to the porphyrin. Finally, one broad signal at $\delta_{\mathrm{H}} 8.79$ was assigned to the pyrrole ring. 
Scheme 3. Synthesis of dendrimers 15-18.

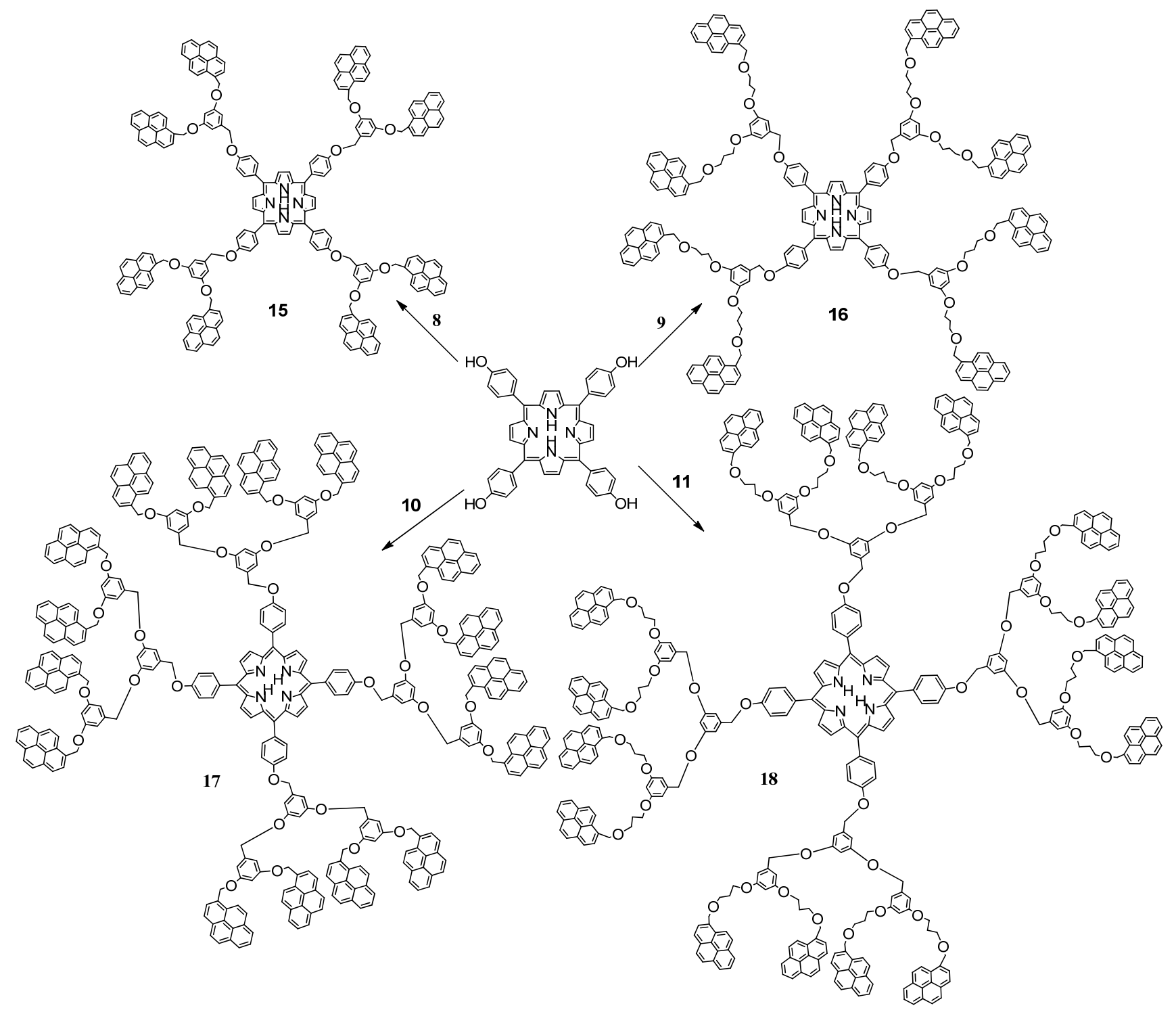

Reagents and Conditions: $\mathrm{Cs}_{2} \mathrm{CO}_{3} / \mathrm{DMF}, 60^{\circ} \mathrm{C}$.

Figure 2. ${ }^{1} \mathrm{H}-\mathrm{NMR}$ spectra of dendrimers 15 (a) and $\mathbf{1 6}$ (b) in $\mathrm{CDCl}_{3}$ at room temperature.

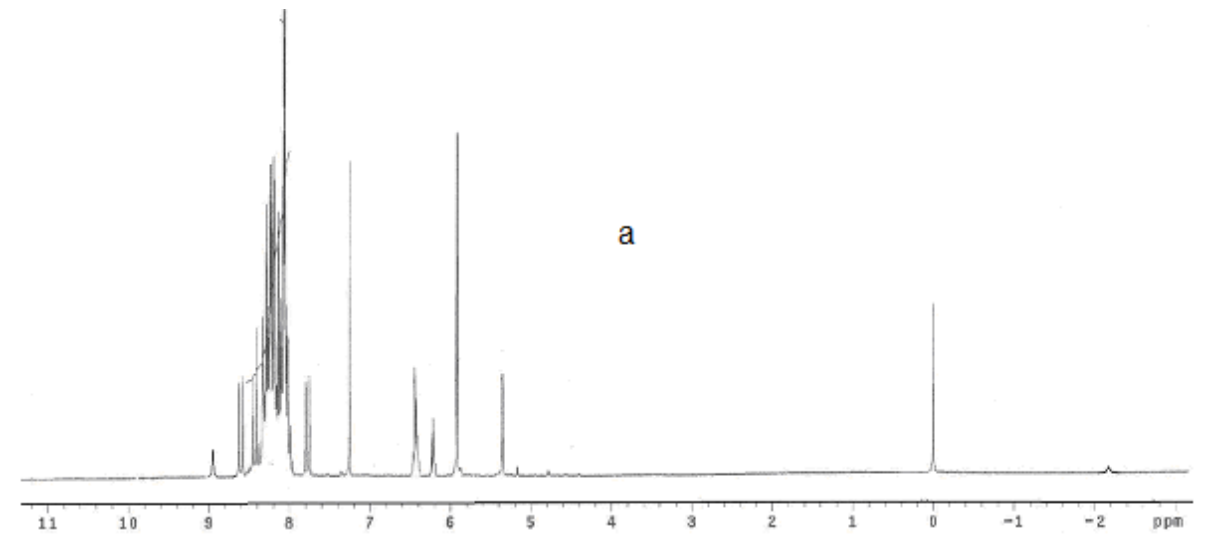


Figure 2. Cont.

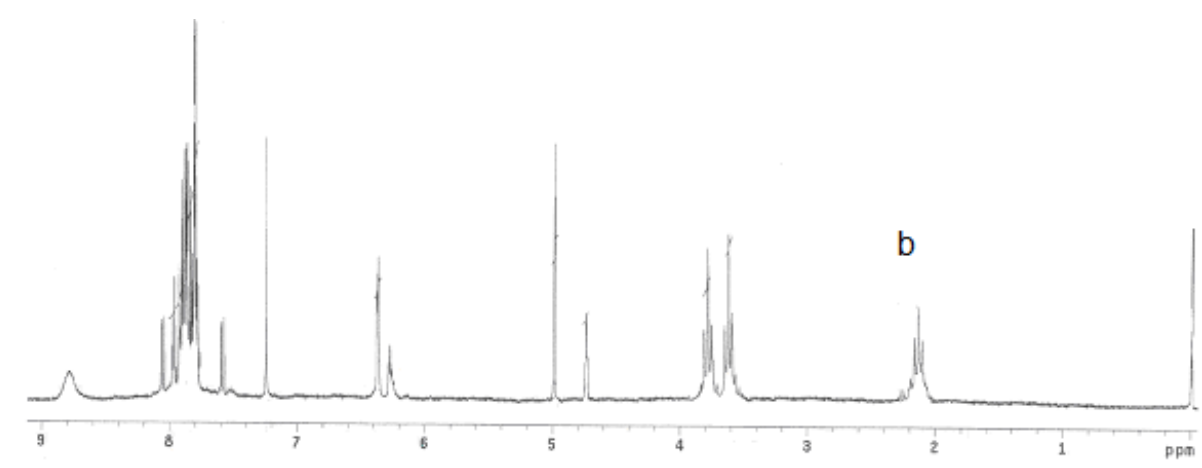

a
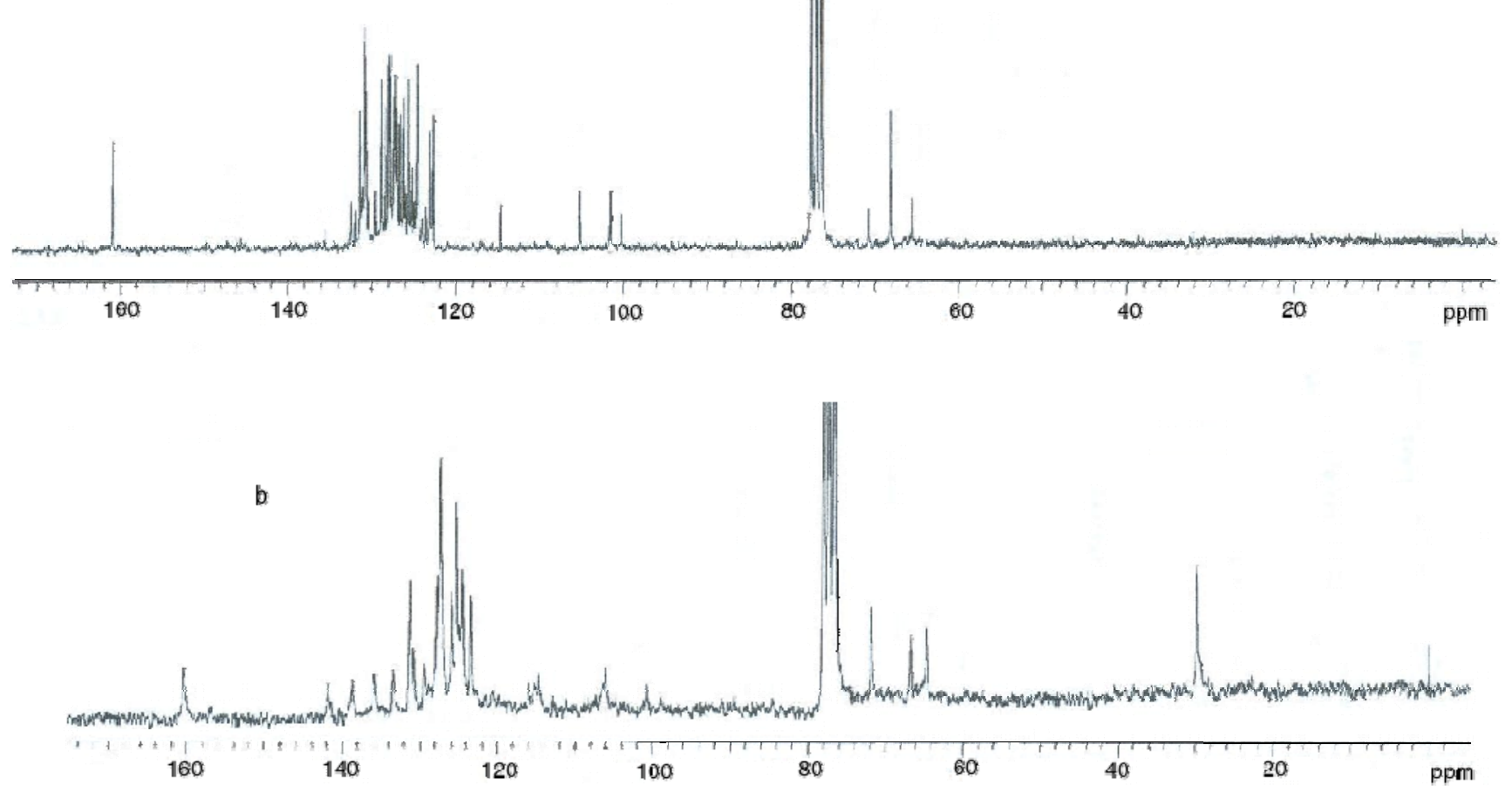

The structures of dendrimers $\mathbf{1 5}-\mathbf{1 8}$ were also confirmed by ${ }^{13} \mathrm{C}-\mathrm{NMR}$, IR and MALDI-TOF mass spectrometry. It was found that all the dendrimers have the expected molecular weight.

In the optical absorption spectra of the dendrimers 15-18 (Figure 3) in two different solvents, $\mathrm{CH}_{2} \mathrm{Cl}_{2}$ and dimethylformamide (DMF), both Soret and Q-bands do not shift upon increasing the concentration up to $10^{-6} \mathrm{M}$, indicating the absence of intermolecular aggregation processes in the ground state. Bands at 329 and $345 \mathrm{~nm}$ due to the pyrene molecules and in the case of dendrimers 16 and 18, bands were observed at 243,277, 328 and $344 \mathrm{~nm}$. The tetraphenylporphyrin clearly shows an intense band at $423 \mathrm{~nm}$ and for the dendrimers 16 and 18, new high energy bands were observed at 453 and at $689 \mathrm{~nm}$, along with the Q- bands (see Table 1). 
Figure 3. UV-vis spectra of dendrimers $15-18$ in DMF at $1 \times 10^{-6} \mathrm{M}$.
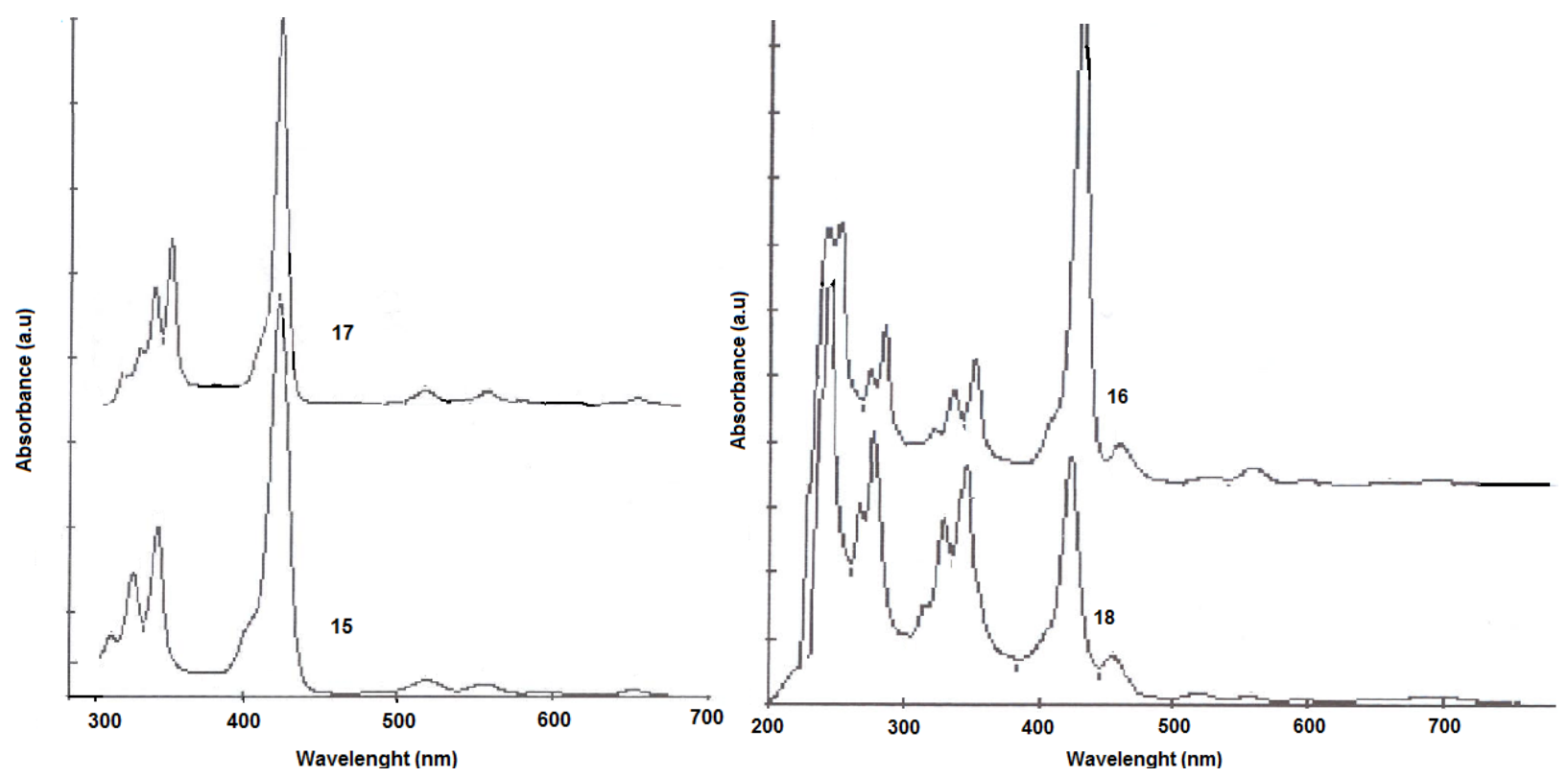

Table 1. UV-vis absorption maxima $\left(\lambda_{\max }\right)$ of dendrimers 15-18.

\begin{tabular}{cc}
\hline Compound & \multicolumn{1}{c}{$\lambda_{\max },(\mathbf{n m})$} \\
\hline $\mathbf{1 5}$ & $329,345,423,518,557,597,653$. \\
$\mathbf{1 7}$ & $315,329,345,375,423,519,555,595,652$ \\
$\mathbf{1 6}$ & $243,277,328,344,422,453,518,551,595,651,689$ \\
$\mathbf{1 8}$ & $244,278,329,345,423,455,519,557,594,652,693$ \\
\hline
\end{tabular}

\subsection{Linear and Third Order Non-Linear Optical Characterization}

Regarding the linear and nonlinear optical properties of the obtained materials, homogeneous film samples were successfully deposited on glass substrates via spin-coating procedures from first and second generation dendrons (compounds 9 and 13, respectively), and from their respective dendrimer systems (compounds $\mathbf{1 6}$ and 18, respectively). Selected samples were chosen for cubic NLO-characterization via the Z-Scan technique.

Figure $4 \mathrm{a}$ shows the linear absorption coefficients evaluated within the visible range for the deposited samples. Indeed, the Beer-Lambert law applies for such semi-transparent films allowing an adequate data analysis and making these materials potential candidates for optical applications due to their appropriate transparency. It is evident from Figure 4a that the highest absorptive properties occur within the 370-550 $\mathrm{nm}$ spectral range, which may indicate additional conjugation of delocalized $\pi$-electrons and multi-directional charge transfer provided by the higher content of dendrons within the dendrimer-based film samples. This suggestion will be explored by means of NLO Z-Scan experiments as explained below. Under this framework, the available laser excitation line for Z-Scan experiments $\left(\lambda_{Z-S c a n}=632.8 \mathrm{~nm}\right)$ is also depicted in this figure (vertical dashed line). At this wavelength, low absorption conditions occur, allowing non-resonant NLO-characterizations of the samples which are a critical point when working with photodegradable organic materials. In fact, relatively small linear absorption coefficients (see Table 2) were evaluated for the studied samples at $\lambda_{Z \text {-Scan. }}$ These values are very useful for the determination of the nonlinear refraction and absorption 
coefficients according to the Z-Scan technique. The thicknesses and estimated linear refractive indices of the studied samples are also shown in Table 2.

Table 2. Linear and cubic nonlinear optical parameters of the dendron/dendrimer-based films measured according to the Z-Scan technique (Closed aperture Z-Scan measurements, @ $\lambda_{\text {Z-Scan }}=633 \mathrm{~nm}, \mathrm{~S} \approx \sim 18 \%$, Rayleigh range: $\mathrm{z}_{0}=3.1 \mathrm{~mm}$ ).

\begin{tabular}{|c|c|c|c|c|c|c|}
\hline $\begin{array}{c}\text { Dendron/ } \\
\text { Dendrimer } \\
\text { Film Sample }\end{array}$ & $\begin{array}{c}\text { Linear } \\
\text { Refractive } \\
\text { Index: } n_{0} @ \\
\lambda_{\text {Z-Scan }}=633 \mathbf{~ n m}\end{array}$ & $\begin{array}{c}\text { Linear } \\
\text { Absorption } \\
\text { Coefficient: } \\
\alpha_{0}(@ 633 \mathrm{~nm}) \\
{\left[\mathrm{m}^{-1}\right]} \\
\end{array}$ & $\begin{array}{c}\text { Sample } \\
\text { Thickness } \\
\text { [nm] }\end{array}$ & $\Delta \phi_{0} / \Delta \psi_{0}$ & $\begin{array}{c}\text { NLO-Refractive } \\
\text { Index: } \gamma / n_{2} Z \text {-Scan } \\
@ \lambda=632 \mathrm{~nm} \times 10^{-8} \\
{\left[\mathrm{~m}^{2} \mathbf{W}^{-1}\right] / \times \mathbf{1 0}^{2}[\mathrm{esu}]}\end{array}$ & $\begin{array}{c}\text { NLO-Absorption: } \\
\beta(\text { TPA or SA) } \\
{\left[\times 1^{-2} \mathbf{m ~ W}^{-1}\right]}\end{array}$ \\
\hline Dendron 9 & $1.56 \pm 0.052$ & $54,185.5$ & 2080 & $0.0 / 0.0$ & $0.0 / 0.0$ & 0.0 \\
\hline Dendron 13 & $1.59 \pm 0.055$ & $117,828.2$ & 6590 & $+4.2 /+0.05$ & $+0.684 /+2.56$ & $+0.162(\mathrm{TPA})$ \\
\hline Dendrimer 16 & $1.68 \pm 0.047$ & $524,837.9$ & 124 & $+0.4 / 0.0$ & $+2.49 /+9.27$ & 0.0 \\
\hline Dendrimer 18 & $1.74 \pm 0.045$ & $1,284,314$ & 116 & $+3.0 /+0.05$ & $+27.7 /+104$ & +9.15 (ТPA) \\
\hline
\end{tabular}

Z-Scan measurements were performed at room conditions on the developed films. The observed non-local effect of these samples is shown in Figures 4(b-d). A rigorous theoretical fitting was performed in order to evaluate both the nonlinear absorptive and refractive properties of these samples. The NLO-response of the developed dendron- and dendrimer-based films was characterized by varying the polarization input planes of the He-Ne laser system in order to explore microscopic material asymmetries or anisotropies throughout the sample structure. In general, since all NLO-measurements were systematically performed with different laser input polarization states (from 0 to $90^{\circ}: s$ - to $p$-polarization, respectively) and the obtained curves are quite similar in each sample, the film structures do not seem to show any significant anisotropic behaviour, thus confirming their amorphous nature. As shown in Figure 4(b) and Table 2, the Z-Scan curves obtained from the pristine, highly transparent dendron-based films (compounds 9 and 13), exhibit negligible nonlinear refraction and absorption when compared to the curves obtained for the dendrimer films under the same laser power regime. Indeed, compound 9 shows a flat Z-Scan curve and only compound $\mathbf{1 3}$ exhibits a typical valley-to-peak Z-Scan transmittance curve. Taking into account the theory developed by Sheik-Bahae et al. and Liu et al. [33-38] it is observed from our measurements that the nonlinear refractive response of the studied samples can be unambiguously determined by these typical Z-Scan transmittance curves. Hence, one can immediately observe that the dendron (13) and dendrimer-based films exhibit positive NLO-refraction coefficients $\left(\gamma\right.$ or $\left.n_{2}>0\right)$.

The respective theoretical fits (TFs) to the obtained Z-Scan transmission data (solid lines) are also shown in Figures 4(b-d). In order to perform TFs according to previous theoretical models, the normalized Z-Scan transmittance $\left(T_{N}\right)$ can be determined as a function of the dimensionless sample position $\left(x=z / z_{0}\right)$, where $\mathrm{z}_{0}$ is the Rayleigh range and $\mathrm{z}$ is the Z-Scan sample position. Hence, the TFs were obtained according to the following equation, considering both nonlinear refraction and absorption effects [38]:

$$
T_{N} \approx 1+\left[4 x /\left(1+x^{2}\right)\left(9+x^{2}\right)\right] \Delta \Phi-\left[2\left(x^{2}+3\right) /\left(1+x^{2}\right)\left(9+x^{2}\right)\right] \Delta \Psi
$$


Figure 4. Linear and nonlinear optical measurements obtained for the pristine reference dendrons (9 and 13) and the dendrimer-based film samples (16 and 18): (a) Linear absorption coefficients of the film samples evaluated within the visible range; (b) Closed aperture Z-Scan data obtained at $\lambda_{\text {Z-Scan }}=632.8 \mathrm{~nm}$ for the first and second generation dendron-based films; and (c-d) closed aperture Z-Scan data obtained for the dendrimer-based films under similar experimental conditions. An estimated experimental error below $5 \%$ is also considered for the Z-Scan data (error bars). Theoretical fitting: continuous lines.
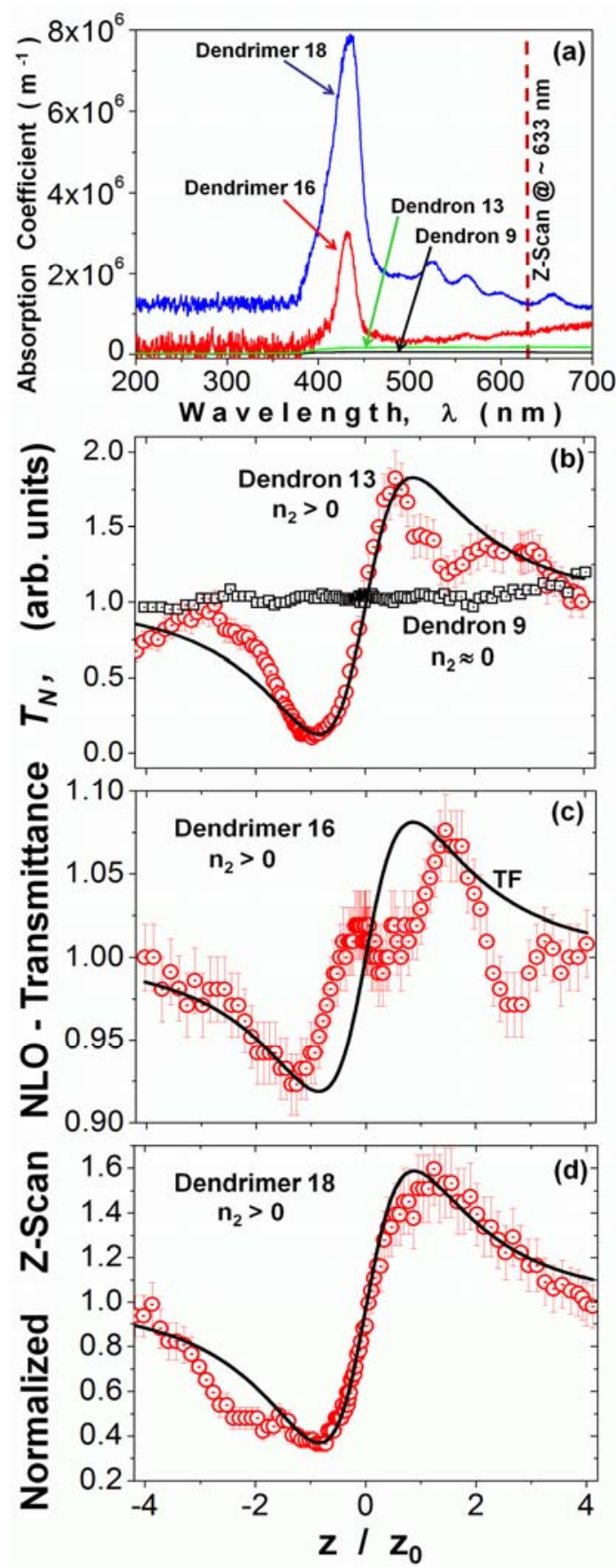

Here, the first term is related to NLO-refractive effects whereas the second one is associated to NLO-absorptive phenomena. Indeed, since some of the obtained Z-Scan curves clearly exhibit a valley-to-peak transmittance asymmetry, NLO absorption effects are also expected [16]. The fitting 
parameters are in this case the induced phase shifts $\Delta \Phi$ or $\Delta \Psi$, respectively. In the former case, the phase shift is given by $\Delta \Phi=2 \pi \gamma I_{0} L_{e f f} / \lambda$, [38] from which the NLO refractive index ( $\gamma$ - coefficient) can be obtained. In the latter case, the phase shift is provoked by the NLO-absorption and is given by $\Delta \Psi=\beta I_{0} L_{E f f} / 2,[38]$ allowing the evaluation of the NLO absorption ( $\beta$-coefficient), either due to two photon (TPA) or multi-photon absorption $(\beta>0)$, and/or saturable absorption $(\beta<0)$. In these equations, $\lambda$ is the laser wavelength, $I_{0}$ is the input beam intensity (at focal spot: $z=0$ ) and $L_{\text {eff }}$ is the effective thickness of the film sample, defined as $L_{e f f}=\left[1-\left(e^{-\alpha_{0} L_{s}}\right)\right]\left(\alpha_{0}\right)^{-1}$, where $\alpha_{0}$ represents the linear absorption coefficient. All these equations are well established and have been proven in early Z-Scan works [33-38]. The theoretical restrictions imposed by these formulas in order to apply such expressions at optimal conditions $\left(\left|\Delta \Phi_{0}\right|<\pi, \mathrm{S} \approx 20 \%\right.$, etc.), are not always fully satisfied in our experimental results due to the large phase shifts and huge nonlinearities. Nevertheless, in most cases (mainly in the case of well defined $\gamma>0$ or $\gamma<0$ curves); our results nearly satisfy these conditions and can be conveniently fitted according to these theoretical formulas. Thus, for comparison purposes and in order to be consistent with the estimation of the $\gamma$ - and $\beta$-values, we assumed their applicability and used them in our experimental results. According to Table 1 the TFs allowed us to evaluate a positive NLO-refractive coefficient in the order of $\gamma=+0.684 \times 10^{-8} \mathrm{~m}^{2} \mathrm{~W}^{-1}$ (or $\mathrm{n}_{2}=+2.56 \times 10^{-2}$ esu) for the dendron-13 based film sample. In contrast, NLO-refractive coefficients as high as $\mathrm{n}_{2}=+9.27 \times 10^{-2}$ esu and $\mathrm{n}_{2}=+104 \times 10^{-2}$ esu were evaluated for the dendrimer-based films (compounds 16 and 18, respectively). The obtained $\gamma / \mathrm{n}_{2}$-values are very large, many orders of magnitude larger than those observed for typical glass substrates or for the classical $\mathrm{CS}_{2}$ standard reference material: $+1.2 \times 10^{-11}$ esu (Z-Scan at $\lambda=10.6 \mu \mathrm{m}$ ) or $6.8 \times 10^{-13}$ esu (DFWM at $\lambda=532 \mathrm{~nm})[33,35]$.

On the other hand, only compounds 13 and 18 exhibited measurable NLO absorption at the implemented experimental conditions, where the positive sign obtained for the $\beta$-coefficients reveal the nature of the NLO absorptive phenomena in these -second generation- based samples; indicating strong multi-photon absorption effects [33-38]. This fact points to the onset of thermal effects during Z-Scan experiments due to long cw-laser irradiation. Indeed, Z-Scan experiments were performed at low laser energy conditions $(\sim 6.6 \mathrm{~mW})$ in order to avoid as much as possible photodegradation of the samples.

\subsection{Crystal Structure Determination}

A suitable crystal of compound 2 (obtained by crystallization from $\mathrm{CH}_{2} \mathrm{Cl}_{2}$ at room temperature) was rolled in epoxy resin and mounted on a glass fiber. Bruker Apex AXS CCD area detector X-Ray diffractometer was the instrument used for the determination. The data were first reduced and corrected for absorption using psi-scans, and then solved using the program SHELL-XS. All nonhydrogen atoms were refined with anisotropic thermal parameters and the hydrogen atoms were refined at calculated positions with thermal parameters constrained to the carbon atom on which they were attached. A summary of the key crystallographic information is given in Table 3. CCDC 838806 contains the supplementary crystallographic data for this paper. These data can be obtained free of charge via www.ccdc.cam.ac.uk/conts/retrieving.html (or from the CCDC, 12 Union Road, Cambridge CB2 1EZ, UK; Fax: +44 1223 336033; E-Mail: deposit@ccdc.cam.ac.uk) 
Table 3. Crystal data and structure refinement.

\begin{tabular}{ll}
\hline Empirical formula & $\mathrm{C}_{17} \mathrm{H}_{12} \mathrm{O}$ \\
Formula weight & 232.27 \\
Temperature & $298(2) \mathrm{K}$ \\
Wavelength & $0.71073 \AA$ \\
Crystal system & Monoclinic \\
Space group & $\mathrm{P} 21 / \mathrm{c}$ \\
Unit cell dimensions & $\mathrm{a}=19.995(3) \AA$ \\
& $\mathrm{b}=8.9672(14) \AA$ \\
& $\mathrm{c}=13.232(2) \AA$ \\
Volume & $2370.8(7) \AA^{3}$ \\
Z & 8 \\
Density (calculated) & $1.301 \mathrm{Mg} / \mathrm{m}^{3}$ \\
Absorption coefficient & $0.079 \mathrm{~mm}{ }^{-1}$ \\
F(000) & 976 \\
Crystal size/shape/color & $0.32 \times 0.23 \times 0.10 \mathrm{~mm} /$ Prism $/$ Colorless \\
Theta range for data collection & 2.04 to $25.38^{\circ}$ \\
Index ranges & $-24 \leq \mathrm{h} \leq 24,-10 \leq \mathrm{k} \leq 10,-15 \leq 1 \leq 15$ \\
Reflections collected & 19076 \\
Independent reflections & $4355[\mathrm{R}(\mathrm{int})=0.0904]$ \\
Completeness to theta $=25.36^{\circ}$ & $99.9 \%$ \\
Absorption correction & None \\
Refinement method & Full-matrix least-squares on $\mathrm{F}^{2}$ \\
Data/restraints/parameters & $4355 / 2 / 331$ \\
Goodness-of-fit on F 2 & 0.804 \\
Final $\mathrm{R}$ indices $[\mathrm{I}>2$ sigma(I) $]$ & $\mathrm{R} 1=0.0473, \mathrm{wR} 2=0.0740$ \\
R indices (all data) & $\mathrm{R} 1=0.1546, \mathrm{wR} 2=0.0954$ \\
Largest diff. peak and hole & 0.124 and $-0.092 \mathrm{e} . \AA^{-3}$ \\
\hline
\end{tabular}

\section{Experimental}

\subsection{General}

Solvents and reagents were purchased as reagent grade and used without further purification. Acetone was distilled over calcium chloride. Tetrahydrofuran was distilled from sodium and benzophenone. Column chromatography was performed on Merck silica gel 60^ (70-230 mesh). ${ }^{1} \mathrm{H}$ - and ${ }^{13} \mathrm{C}$-NMR were recorded on a Varian-Unity-200 MHz with tetramethylsilane (TMS) as an internal reference. Infrared (IR) spectra were measured on a spectrophotometer Nicolet FT-SSX. Elemental analysis was determined by Galbraith Laboratories, Inc. (Knoxville, TN, USA). FAB+ mass spectra were taken on a JEOL JMS AX505 HA instrument. MALDI-TOF mass spectra were taken on a Bruker Omni FLEX instrument.

\subsection{Synthesis of Dendrons and Dendrimers}

1-Pyrenemethanol (2): 97\% Lithium aluminum hydride $(1.7 \mathrm{mmol})$ was dissolved in dry THF $(50 \mathrm{~mL})$. To this solution, compound $1(6 \mathrm{mmol})$ dissolved in dry THF $(15 \mathrm{~mL})$ was added dropwise 
using an addition funnel. The reaction was carried at $0{ }^{\circ} \mathrm{C}$ for $4 \mathrm{~h}$. After this time, water $(10 \mathrm{~mL})$ was added and the reaction mixture was filtered through Celite ${ }^{\circledR}$. The solvent was evaporated and the residue was dissolved in dichloromethane. The resulting solution was dried with sodium sulfate, filtered and the product was vacuum dried and purified by column chromatography $\left(\mathrm{Al}_{2} \mathrm{O}_{3}\right.$, hexane $)$, as a yellow powder, yield $5.82 \mathrm{mmol}$ (97\%). m.p. $123-125{ }^{\circ} \mathrm{C}$. FTIR (KBr pellet, $\left.\mathrm{cm}^{-1}\right)$ : 3278, 1594, 1180, 1064, 1008, 842, 705. UV-vis $\left(\mathrm{CHCl}_{3}, \mathrm{~nm}\right) \lambda_{\max }: 344,328,314,277,266,252,243 .{ }^{1} \mathrm{H}-\mathrm{NMR}$ $\left(\mathrm{CDCl}_{3}\right), \delta(\mathrm{ppm}): 1.83(\mathrm{~s}, 1 \mathrm{H}, \mathrm{OH}), 5.36\left(\mathrm{~s}, 2 \mathrm{H}, \mathrm{Py}-\mathrm{CH}_{2}-\mathrm{O}\right), 7.96-8.34\left(\mathrm{~m}, 9 \mathrm{H}, \mathrm{H}_{\mathrm{Py}}\right) .{ }^{13} \mathrm{C}-\mathrm{NMR}$ $\left(\mathrm{CDCl}_{3}\right), \delta(\mathrm{ppm}): 63.8\left(\mathrm{CH}_{2}\right), 122.9\left(\mathrm{C}_{\text {Рy }}\right), 124.6\left(\mathrm{C}_{\text {Рy }}\right), 124.7\left(\mathrm{C}_{\text {Рy }}\right), 124.9\left(\mathrm{C}_{\text {Рy }}\right), 125.2\left(\mathrm{C}_{\text {Рy }}\right)$, $125.9\left(\mathrm{C}_{\text {Py }}\right), 127.3\left(\mathrm{C}_{\text {Py }}\right), 127.4\left(\mathrm{C}_{\text {Py }}\right), 127.8\left(\mathrm{C}_{\text {Py }}\right), 128.8\left(\mathrm{C}_{\text {Py }}\right), 130.7\left(\mathrm{C}_{\text {Py }}\right), 131.2\left(\mathrm{C}_{\text {Py }}\right), 133.7\left(\mathrm{C}_{\mathrm{ipso}}\right)$. MS (m/z): $232[\mathrm{M}]^{+}$. Calc. for $\mathrm{C}_{17} \mathrm{H}_{12} \mathrm{O}: \mathrm{C}, 87.90 ; \mathrm{H}, 5.21(\%)$; Found: C, 87.91; H, $5.20(\%)$.

1-Chloromethylpyrene (3): A solution of pyridine $(6.1 \mathrm{mmol})$ and $\mathrm{SOCl}_{2}(6.1 \mathrm{mmol})$ in $\operatorname{dry~} \mathrm{CH}_{2} \mathrm{Cl}_{2}$ $(50 \mathrm{~mL})$ was added to $2(6 \mathrm{mmol})$, and then this mixture was cooled to $-10{ }^{\circ} \mathrm{C}$. The reaction was carried out in nitrogen atmosphere for $7 \mathrm{~h}$. After this, the solvent was evaporated and the resulting oil was dried and purified by silica gel chromatography using a mixture of hexane-dichloromethane $2: 1$ as an eluent to afford 1-chloromethylpyrene (3) as a brownish powder, yield 5.76 mmol (96\%). m.p. 148-149 ${ }^{\circ} \mathrm{C}$. FTIR (KBr pellet, $\left.\mathrm{cm}^{-1}\right): 3423,3042,1593,1253,1182,841,757,689$. UV-vis $\left(\mathrm{CHCl}_{3}\right.$, nm) $\lambda_{\max }: 349,339,332,279,272,268,254,244 .{ }^{1} \mathrm{H}-\mathrm{NMR}\left(\mathrm{CDCl}_{3}\right) \delta$ (ppm): 5.25 (s, 2H, Py-CH$\left.-\mathrm{Cl}\right)$, 7.97-8.19 (m, 9H, $\left.\mathrm{H}_{\text {pyr }}\right) .{ }^{13} \mathrm{C}-\mathrm{NMR}\left(\mathrm{CDCl}_{3}\right) \delta(\mathrm{ppm}): 44.7\left(\mathrm{CH}_{2}\right), 122.7\left(\mathrm{C}_{\text {Py }}\right), 124.5\left(\mathrm{C}_{\text {Py }}\right), 124.7\left(\mathrm{C}_{\text {Py }}\right)$, $125.0\left(\mathrm{C}_{\text {Py }}\right), 125.6\left(\mathrm{C}_{\text {Рy }}\right), 126.1\left(\mathrm{C}_{\text {Py }}\right), 127.2\left(\mathrm{C}_{\text {Py }}\right), 127.6\left(\mathrm{C}_{\text {Рy }}\right), 127.9\left(\mathrm{C}_{\text {Рy }}\right), 128.3\left(\mathrm{C}_{\text {Рy }}\right), 129.1\left(\mathrm{C}_{\text {Py }}\right)$, $130.2\left(\mathrm{C}_{\mathrm{Py}}\right), 130.6\left(\mathrm{C}_{\mathrm{Py}}\right), 131.1\left(\mathrm{C}_{\mathrm{Py}}\right), 131.9\left(\mathrm{C}_{\mathrm{ppso}}\right) . \mathrm{MS}(\mathrm{m} / \mathrm{z}): 250[\mathrm{M}]^{+}$. Calc. for $\mathrm{C}_{17} \mathrm{H}_{11} \mathrm{Cl}: \mathrm{C}, 81.44$; $\mathrm{H}, 4.42 ; \mathrm{Cl}, 14.14$ (\%); found: $\mathrm{C}, 81.44 ; \mathrm{H}, 4.42(\%)$.

1-((3-Chloropropoxy)methyl)pyrene (4): A mixture of 1-pyrenemethanol (2, $6 \mathrm{mmol})$, potassium carbonate $(18 \mathrm{mmol})$ in dry acetone $(100 \mathrm{~mL})$ was heated to reflux and stirred vigorously in nitrogen atmosphere for $30 \mathrm{~min}$. Then, 1-bromo-3-chloro propane $(6.1 \mathrm{mmol})$ dissolved in dry acetone $(40 \mathrm{~mL})$ was added dropwise and the reaction was continued for 7 days. The mixture was allowed to cool and the precipitate was filtered. The filtrate was evaporated to dryness under reduced pressure. The residue, dissolved in diethyl ether, was washed with an aqueous solution of $5 \% \mathrm{Na}_{2} \mathrm{CO}_{3}$ (three times). The organic layer was dried and evaporated to dryness and purified by silica gel chromatography using a mixture of hexane-dichloromethane 2:1 as an eluent to afford 1-[(3-chloropropoxy)methyl]pyrene (4), as a yellow oil, yielding $2.34 \mathrm{mmol}$ (39\%). FTIR (KBr pellet, $\left.\mathrm{cm}^{-1}\right): 3042,2859,1077,845,708$. UV-vis $\left(\mathrm{CHCl}_{3}, \mathrm{~nm}\right) \lambda_{\max }: 341,332,325,316,312,275,269,264,250,241,214,204 .{ }^{1} \mathrm{H}-\mathrm{NMR}$ $\left(\mathrm{CDCl}_{3}\right) \delta(\mathrm{ppm}): 2.03\left(\mathrm{~m}, 2 \mathrm{H}, \mathrm{CH}_{2}\right), 3.63\left(\mathrm{~m}, 2 \mathrm{H}, \mathrm{Ar}-\mathrm{CH}_{2}-\mathrm{Cl}, J=6.4 \mathrm{~Hz}\right), 4.09$ (m, 2H, Ar-CH $-\mathrm{O}$, $J=1.6 \mathrm{~Hz}), 5.12$ (s, 2H, Py-CH $2-\mathrm{O}), 7.90-8.32(\mathrm{~m}, 9 \mathrm{H}, \mathrm{Ar}-\mathrm{H}) .{ }^{13} \mathrm{C}-\mathrm{NMR}\left(\mathrm{CDCl}_{3}\right) \delta(\mathrm{ppm}): 32.7$ $\left(\mathrm{CH}_{2}\right), 42.0\left(\mathrm{CH}_{2}-\mathrm{Cl}\right), 66.6\left(\mathrm{CH}_{2}-\mathrm{O}\right), 71.2\left(\mathrm{Py}_{-} \mathrm{CH}_{2}-\mathrm{O}\right), 117.3\left(\mathrm{C}_{\mathrm{Py}}\right), 122.3\left(\mathrm{C}_{\text {Py }}\right), 124.4\left(\mathrm{C}_{\text {Py }}\right), 124.6$ $\left(\mathrm{C}_{\text {Py }}\right), 124.8\left(\mathrm{C}_{\text {Py }}\right), 125.1\left(\mathrm{C}_{\text {Py }}\right), 125.8\left(\mathrm{C}_{\text {Py }}\right), 126.8\left(\mathrm{C}_{\text {Py }}\right), 127.3\left(\mathrm{C}_{\text {Py }}\right), 127.6\left(\mathrm{C}_{\text {Py }}\right), 129.2\left(\mathrm{C}_{\text {Py }}\right), 130.7$ $\left(\mathrm{C}_{\mathrm{Py}}\right), 131.1\left(\mathrm{C}_{\mathrm{Py}}\right), 131.2\left(\mathrm{C}_{\mathrm{Py}}\right), 131.3\left(\mathrm{C}_{\mathrm{Py}}\right), 134.7\left(\mathrm{C}_{\mathrm{ipso}}\right)$. MS $(\mathrm{m} / \mathrm{z}): 308[\mathrm{M}]^{+}$. Calc. for $\mathrm{C}_{20} \mathrm{H}_{17} \mathrm{ClO}: \mathrm{C}$, 77.79; H, 5.55 (\%); found: C, 77.77; H, 5.57 (\%). 


\subsubsection{General Procedure}

A mixture of $3,4,8$ or $9(6 \mathrm{mmol})$ and cesium carbonate $(12 \mathrm{mmol})$ in DMF $(20 \mathrm{~mL})$ was stirred vigorously in nitrogen atmosphere for $30 \mathrm{~min}$. 3,5-Dihydroxybenzyl alcohol (5, $2.9 \mathrm{mmol})$ dissolved in DMF $(10 \mathrm{~mL})$ was added dropwise and the reaction was continued for 3 days. The mixture was filtered. The filtrate was evaporated to dryness under reduced pressure. The organic layer was dried and evaporated to dryness and purified by silica gel chromatography using a mixture of hexane-dichloromethane 2:1 as an eluent.

(3,5-bis(Pyren-1-ylmethoxy)phenyl)methanol (6): Yellow powder, yield $1.11 \mathrm{mmol}(38 \%)$. FTIR (KBr pellet, $\left.\mathrm{cm}^{-1}\right)$ : 3430, 3039, 1593, 1448, 1352, 1287, 1165, 1021, 842, 707. UV-vis $\left(\mathrm{CHCl}_{3}, \mathrm{~nm}\right) \lambda_{\max }$ : 344, 336, 328, 319, 314, 294, 277, 271, 267, 253, 244. ${ }^{1} \mathrm{H}-\mathrm{NMR}\left(\mathrm{CDCl}_{3}\right), \delta(\mathrm{ppm}): 1.62(\mathrm{~s}, 1 \mathrm{H}, \mathrm{OH})$, 4.69 (s, 2H, Ar- $\left.\mathrm{CH}_{2}-\mathrm{OH}\right), 5.72$ (s, 4H, Py- $\left.\mathrm{CH}_{2}-\mathrm{O}\right), 6.81$ (s, 3H, Ar), 7.97-8.29 (m, 18H, $\mathrm{H}_{\mathrm{Py}}$ ). ${ }^{13} \mathrm{C}-\mathrm{NMR}\left(\mathrm{CDCl}_{3}\right), \delta(\mathrm{ppm}): 65.3\left(\mathrm{Ar}_{-} \mathrm{CH}_{2}-\mathrm{O}\right), 68.8\left(\mathrm{Py}-\mathrm{CH}_{2}-\mathrm{O}\right), 101.4\left(\mathrm{C}_{\mathrm{Ar}}\right), 106.0\left(\mathrm{C}_{\mathrm{Ar}}\right), 122.9\left(\mathrm{C}_{\mathrm{Py}}\right)$, $124.6\left(\mathrm{C}_{\text {Рy }}\right), 124.9\left(\mathrm{C}_{\text {Рy }}\right), 125.4\left(\mathrm{C}_{\text {Рy }}\right), 126.0\left(\mathrm{C}_{\text {Рy }}\right), 126.8\left(\mathrm{C}_{\text {Рy }}\right), 127.3\left(\mathrm{C}_{\text {Рy }}\right), 127.6\left(\mathrm{C}_{\text {Рy }}\right), 128.0\left(\mathrm{C}_{\text {Рy }}\right)$, $129.2\left(\mathrm{C}_{\mathrm{Py}}\right), 129.5\left(\mathrm{C}_{\mathrm{Py}}\right), 130.7\left(\mathrm{C}_{\mathrm{Py}}\right), 131.1\left(\mathrm{C}_{\mathrm{Py}}\right), 131.5\left(\mathrm{C}_{\mathrm{ipso}} \mathrm{Py}\right), 143.5\left(\mathrm{C}_{\mathrm{ipso}} \mathrm{Ar}\right), 160.3\left(\mathrm{C}_{\mathrm{ipso}} \mathrm{Ar}\right)$. MS (m/z): $568[\mathrm{M}]^{+}$. Calc. for $\mathrm{C}_{41} \mathrm{H}_{28} \mathrm{O}_{3}: \mathrm{C}, 86.60 ; \mathrm{H}, 4.96(\%)$; Found: C, 86.60; H, $4.98(\%)$.

(3,5-bis(3-(pyren-1-ylmethoxy)propoxy)phenyl)methanol (7): Yellow powder, yield $0.72 \mathrm{mmol}$ (25\%). FTIR (KBr pellet, $\mathrm{cm}^{-1}$ ): 3350, 3038, 2946, 2857, 1599, 1497, 1165, 1088, 1054, 844, 704. UV-vis $\left(\mathrm{CH}_{3} \mathrm{OH}, \mathrm{nm}\right) \lambda_{\max }: 341,333,326,292,275,251,241,217,207 .{ }^{1} \mathrm{H}-\mathrm{NMR}\left(\mathrm{CDCl}_{3}\right) \delta(\mathrm{ppm}): 1.68$ (br, $1 \mathrm{H}, \mathrm{OH}), 2.03\left(\mathrm{~m}, 4 \mathrm{H}, \mathrm{CH}_{2}\right), 3.73\left(\mathrm{t}, 4 \mathrm{H}, \mathrm{CH}_{2}-\mathrm{O}, J=6.0 \mathrm{~Hz}\right), 3.90$ (t, 4H, $\mathrm{CH}_{2}-\mathrm{O}, J=6.0 \mathrm{~Hz}$ ), 4.35 (s, $\left.2 \mathrm{H}, \mathrm{Ar}-\mathrm{CH}_{2}-\mathrm{O}\right), 5.15\left(\mathrm{~s}, 4 \mathrm{H}, \mathrm{Py}-\mathrm{CH}_{2}-\mathrm{O}\right), 6.11(\mathrm{t}, 1 \mathrm{H}, \mathrm{Ar}, J=2.2 \mathrm{~Hz}), 6.21(\mathrm{~d}, 2 \mathrm{H}, \mathrm{Ar}, J=2.2 \mathrm{~Hz})$, 7.88-8.27 (m, 18H, Py). ${ }^{13} \mathrm{C}-\mathrm{NMR}\left(\mathrm{CDCl}_{3}\right) \delta(\mathrm{ppm}): 29.6\left(\mathrm{CH}_{2}\right), 64.4\left(\mathrm{CH}_{2}-\mathrm{O}\right), 65.1\left(\mathrm{CH}_{2}-\mathrm{O}\right), 66.4$ $\left(\mathrm{Ar}-\mathrm{CH}_{2}-\mathrm{O}\right), 71.6\left(\mathrm{Py}_{-} \mathrm{CH}_{2}-\mathrm{O}\right), 100.0\left(\mathrm{C}_{\mathrm{Ar}}\right), 104.7\left(\mathrm{C}_{\mathrm{Ar}}\right), 123.4-130.7\left(\mathrm{C}_{\mathrm{py}}\right), 131.3\left(\mathrm{C}_{\text {ipso }} \mathrm{Py}\right), 142.8$ $\left(\mathrm{C}_{\text {ipso }} \mathrm{Ar}\right), 160.0\left(\mathrm{C}_{\mathrm{ipso}} \mathrm{Ar}\right)$. MS (m/z): $684(\mathrm{M})$. Calc. for $\mathrm{C}_{47} \mathrm{H}_{40} \mathrm{O}_{5}: \mathrm{C}, 82.43 ; \mathrm{H}, 5.89$ (\%); found: C, $82.45 ; \mathrm{H}, 5.85(\%)$.

(3,5-bis((3,5-bis(Pyren-1-ylmethoxy)benzyl)oxy)phenyl)methanol (10): Yellow powder, yield $1.02 \mathrm{mmol}$ (35\%). FTIR (KBr pellet, $\mathrm{cm}^{-1}$ ): 3438, 2958, 2926, 2856, 1732, 1596, 1462, 1271, 1160, 845, 738, 707. UV-vis $\left(\mathrm{CHCl}_{3}, \mathrm{~nm}\right) \lambda_{\max }: 346,330,315,278,269,244 .{ }^{1} \mathrm{H}-\mathrm{NMR}\left(\mathrm{CDCl}_{3}\right), \delta(\mathrm{ppm}): 2.19(\mathrm{~s}, 1 \mathrm{H}$, $\mathrm{OH}), 4.58$ (s, 2H, Ar- $\left.\mathrm{CH}_{2}-\mathrm{OH}\right), 5.03$ (s, 4H, Ar- $\left.\mathrm{CH}_{2}-\mathrm{O}\right), 5.75$ (s, 8H, Py-CH2-O), 6.85 (m, 9H, Ar), 7.97-8.32 (m, 36H, H $\left.\mathrm{H}_{\mathrm{Py}}\right) .{ }^{13} \mathrm{C}-\mathrm{NMR}\left(\mathrm{CDCl}_{3}\right), \delta(\mathrm{ppm}): 64.5\left(\mathrm{Ar}_{-} \mathrm{CH}_{2}-\mathrm{O}\right), 68.1\left(\mathrm{CH}_{2}-\mathrm{O}-\mathrm{Ar}\right), 70.4$ $\left(\mathrm{Py}-\mathrm{CH}_{2}-\mathrm{O}\right), 100.1\left(\mathrm{HC}_{\mathrm{Ar}}\right), 101.8\left(\mathrm{HC}_{\mathrm{Ar}}\right), 105.0\left(\mathrm{HC}_{\mathrm{Ar}}\right), 106.5\left(\mathrm{HC}_{\mathrm{Ar}}\right), 122.9-130.8\left(\mathrm{C}_{\mathrm{py}}\right), 131.1\left(\mathrm{C}_{\mathrm{ipso}}\right.$ Py), $131.2\left(\mathrm{C}_{\mathrm{ipso}}\right), 132.2\left(\mathrm{C}_{\mathrm{ipso}}\right), 138.2\left(\mathrm{C}_{\mathrm{ipso}}\right), 141.33\left(\mathrm{C}_{\mathrm{ipso}}\right), 160.3\left(\mathrm{C}_{\mathrm{ipso}}\right)$. MALDI-TOF MS $(\mathrm{m} / z)$ : 1240 (M). Calc. for $\mathrm{C}_{89} \mathrm{H}_{60} \mathrm{O}_{7}$ : C, 86.11; H, 4.87 (\%); found: C, 86.12; H, $4.85(\%)$.

(3,5-bis((3,5-bis(3-(Pyren-1-ylmethoxy)propoxy)benzyl)oxy)phenyl)methanol (11): White powder, yield $1.44 \mathrm{mmol}$ (49\%). FTIR (KBr pellet, $\left.\mathrm{cm}^{-1}\right)$ : 3421, 3008, 2957, 2926, 2870, 1729, 1597, 1164, 1078, 847, 756, 708. UV-vis $\left(\mathrm{CHCl}_{3}, \mathrm{~nm}\right) \lambda_{\text {max }}: 344,328,316,277,266,245 .{ }^{1} \mathrm{H}-\mathrm{NMR}\left(\mathrm{CDCl}_{3}\right) \delta$ (ppm): $2.16(\mathrm{~s}, 1 \mathrm{H}, \mathrm{OH}), 2.03\left(\mathrm{~m}, 8 \mathrm{H}, \mathrm{CH}_{2}\right), 3.78\left(\mathrm{~m}, 16 \mathrm{H}, \mathrm{CH}_{2}-\mathrm{O}\right), 4.56\left(\mathrm{~s}, 2 \mathrm{H}, \mathrm{CH}_{2}-\mathrm{OH}\right), 5.18$ (s, $4 \mathrm{H}, \mathrm{CH}_{2}-\mathrm{O}$ ), 5.21 (s, 8H, Py- $\mathrm{CH}_{2}-\mathrm{O}$ ), 6.20 (br, 3H, Ar), 6.41 (br, 6H, Ar), 7.96-8.37 (m, 36H, Py). 
${ }^{13} \mathrm{C}-\mathrm{NMR}\left(\mathrm{CDCl}_{3}\right), \delta(\mathrm{ppm}): 29.6\left(\mathrm{CH}_{2}\right), 61.8\left(\mathrm{CH}_{2}-\mathrm{O}\right), 64.5\left(\mathrm{CH}_{2}-\mathrm{O}\right), 66.5\left(\mathrm{CH}_{2}-\mathrm{O}\right), 69.3\left(\mathrm{CH}_{2}-\mathrm{O}\right)$, $71.8\left(\mathrm{Py}_{-} \mathrm{CH}_{2}-\mathrm{O}\right), 100.4\left(\mathrm{HC}_{\mathrm{Ar}}\right), 104.7\left(\mathrm{HC}_{\mathrm{Ar}}\right), 105.3\left(\mathrm{HC}_{\mathrm{Ar}}\right), 105.7\left(\mathrm{HC}_{\mathrm{Ar}}\right), 123.1-129.3\left(\mathrm{C}_{\mathrm{py}}\right), 130.7$ $\left(\mathrm{C}_{\mathrm{ipso}}\right), 131.2\left(\mathrm{C}_{\mathrm{ipso}}\right), 131.3\left(\mathrm{C}_{\mathrm{ipso}}\right), 160.1\left(\mathrm{C}_{\mathrm{ipso}}\right)$. MALDI-TOF MS $(\mathrm{m} / \mathrm{z})$ : $1472(\mathrm{M})$. Calc. for $\mathrm{C}_{101} \mathrm{H}_{84} \mathrm{O}_{11}$ : C, 82.31; H, 5.75 (\%); found: C, 82.33; H, $5.75(\%)$.

\subsubsection{General Procedure}

A solution of pyridine $(6.1 \mathrm{mmol})$ and $\mathrm{SOCl}_{2}(6.1 \mathrm{mmol})$ in dry $\mathrm{CH}_{2} \mathrm{Cl}_{2}(100 \mathrm{~mL})$ was added to 6 , 7, 10 or $11(6 \mathrm{mmol})$, and then this mixture was cooled to $0{ }^{\circ} \mathrm{C}$. The reaction was carried out in nitrogen atmosphere for $7 \mathrm{~h}$. After this, the solvent was evaporated and the resulting oil was dried and purified by silica gel chromatography using a mixture of hexane-dichloromethane 2:1 as an eluent.

1,1'-(((5-(Chloromethyl)-1,3-phenylene)bis(oxy))bis(methylene))dipyrene (8): Yellow powder, yield $5.28 \mathrm{mmol}$ (88\%). FTIR (KBr pellet, $\mathrm{cm}^{-1}$ ): 3442, 3043, 1593, 1463, 1381, 1322, 1172, 1043, 844, 712. UV-vis $\left(\mathrm{CHCl}_{3}\right.$, nm) $\lambda_{\max }$ : 344, 335, 328, 318, 314, 293, 276, 270, 265, 259, 242, 219, 204. ${ }^{1} \mathrm{H}-\mathrm{NMR}\left(\mathrm{CDCl}_{3}+\mathrm{DMSO}_{-} \mathrm{d}_{6}\right), \delta(\mathrm{ppm}): 4.60\left(\mathrm{~s}, 2 \mathrm{H}, \mathrm{CH}_{2}-\mathrm{Cl}\right), 5.76\left(\mathrm{~s}, 4 \mathrm{H}, \mathrm{Py}_{-} \mathrm{CH}_{2}-\mathrm{O}\right), 6.84(\mathrm{~s}, 3 \mathrm{H}$, $\mathrm{Ar}, J=2.2 \mathrm{~Hz}), 8.00-8.33\left(\mathrm{~m}, 18 \mathrm{H}, \mathrm{H}_{\mathrm{Py}}\right) \cdot{ }^{13} \mathrm{C}-\mathrm{NMR}\left(\mathrm{CDCl}_{3}\right), \delta(\mathrm{ppm}): 45.7\left(\mathrm{Ar}_{-} \mathrm{CH}_{2}-\mathrm{Cl}\right), 68.3$ $\left(\mathrm{Py}-\mathrm{CH}_{2}-\mathrm{O}\right), 101.5\left(\mathrm{C}_{\mathrm{Ar}}\right), 107.4\left(\mathrm{C}_{\mathrm{Ar}}\right), 122.4\left(\mathrm{C}_{\mathrm{py}}\right), 124.1\left(\mathrm{C}_{\mathrm{py}}\right), 124.9\left(\mathrm{C}_{\mathrm{py}}\right), 125.6\left(\mathrm{C}_{\mathrm{py}}\right), 126.5\left(\mathrm{C}_{\mathrm{py}}\right)$, $126.8\left(\mathrm{C}_{\mathrm{py}}\right), 127.1\left(\mathrm{C}_{\mathrm{py}}\right), 127.5\left(\mathrm{C}_{\mathrm{py}}\right), 128.9\left(\mathrm{C}_{\mathrm{py}}\right), 130.0\left(\mathrm{C}_{\mathrm{py}}\right), 130.5\left(\mathrm{C}_{\mathrm{py}}\right), 130.9\left(\mathrm{C}_{\text {ipso }}\right.$ Py $), 139.2$ $\left(\mathrm{C}_{\text {ipso }} \mathrm{Ar}\right), 159.6\left(\mathrm{C}_{\text {ipso }} \mathrm{Ar}\right)$. MS $(\mathrm{m} / \mathrm{z}): 586[\mathrm{M}]^{+}$. Calc. for $\mathrm{C}_{41} \mathrm{H}_{27} \mathrm{ClO}_{2}: \mathrm{C}, 83.88 ; \mathrm{H}, 4.64(\%)$; Found: C, 83.86; H, 4.67 (\%).

1,1'-(((((5-(Chloromethyl)-1,3-phenylene)bis(oxy))bis(propane-3,1-diyl))bis(oxy))bis(methylene))di-pyrene (9): Yellow powder, yield $4.80 \mathrm{mmol}(80 \%)$. FTIR (KBr pellet, $\left.\mathrm{cm}^{-1}\right): 3350,3038,2946,2857,1599$, 1497, 1165, 1088, 1054, 844, 704. UV-vis $\left(\mathrm{CH}_{3} \mathrm{OH}, \mathrm{nm}\right) \lambda_{\max }: 341,333,326,292,275,251,241,217$, 207. ${ }^{1} \mathrm{H}-\mathrm{NMR}\left(\mathrm{CDCl}_{3}\right) \delta(\mathrm{ppm}): 2.03\left(\mathrm{~m}, 4 \mathrm{H}, \mathrm{CH}_{2}\right), 3.73\left(\mathrm{t}, 4 \mathrm{H}, \mathrm{CH}_{2}-\mathrm{O}, J=6.0 \mathrm{~Hz}\right), 3.90(\mathrm{t}, 4 \mathrm{H}$, $\left.\mathrm{CH}_{2}-\mathrm{O}, J=6.0 \mathrm{~Hz}\right), 4.35$ (s, 2H, Ar- $\left.\mathrm{CH}_{2}-\mathrm{OH}\right), 5.15$ (s, 4H, Py-CH$\left.{ }_{2}-\mathrm{O}\right), 6.11(\mathrm{t}, 1 \mathrm{H}, \mathrm{Ar}, J=2.2 \mathrm{~Hz})$, $6.21(\mathrm{~d}, 2 \mathrm{H}, \mathrm{Ar}, \mathrm{J}=2.2 \mathrm{~Hz}), 7.88-8.27(\mathrm{~m}, 18 \mathrm{H}, \mathrm{Py}) .{ }^{13} \mathrm{C}-\mathrm{NMR}\left(\mathrm{CDCl}_{3}\right) \delta(\mathrm{ppm}): 29.6\left(\mathrm{CH}_{2}\right), 46.3$ (Ar-CH $\left.\mathrm{CH}_{2}-\mathrm{Cl}\right), 64.4\left(\mathrm{CH}_{2}-\mathrm{O}\right), 65.1\left(\mathrm{CH}_{2}-\mathrm{O}\right), 71.6\left(\mathrm{Py}_{-} \mathrm{CH}_{2}-\mathrm{O}\right), 100.0\left(\mathrm{H}-\mathrm{C}_{\mathrm{Ar}}\right), 104.7\left(\mathrm{H}-\mathrm{C}_{\mathrm{Ar}}\right), 123.4-130.7$ $\left(\mathrm{C}_{\text {pireno }}\right), 131.31\left(\mathrm{C}_{\mathrm{ipso}} \mathrm{py}\right), 142.86\left(\mathrm{C}_{\mathrm{ipso}} \mathrm{Ar}\right), 160.01\left(\mathrm{C}_{\mathrm{ipso}} \mathrm{Ar}\right) . \mathrm{MS}(\mathrm{m} / \mathrm{z})$ : $702(\mathrm{M})$. Calc. for $\mathrm{C}_{47} \mathrm{H}_{39} \mathrm{ClO}_{4}$ : C, 80.27; H, 5.59 (\%); found: C, 80.25; H, $5.58(\%)$.

1,1', 1", 1'"--((((((5-(Chloromethyl)-1,3-phenylene)bis(oxy))bis(methylene))bis(benzene-5, 3,1-triyl)) tetrakis(oxy))tetrakis(methylene))tetrapyrene (12): Yellow powder, yield 2.52 mmol (42\%). FTIR ( $\mathrm{KBr}$ pellet, $\left.\mathrm{cm}^{-1}\right): 3443,3041,1596,1466,1378,1321,1170,1043,844,711 . \mathrm{UV}$-vis $\left(\mathrm{CHCl}_{3}, \mathrm{~nm}\right)$ $\lambda_{\text {max }}: 344,335,328,318,314,293,276,270,265,259,242,219,204 .{ }^{1} \mathrm{H}-\mathrm{NMR}\left(\mathrm{CDCl}_{3}+\mathrm{DMSO}_{6}\right), \delta$ (ppm): 4.61 (s, 2H, CH $2-\mathrm{Cl}), 5.75$ (s, 12H, $\left.\mathrm{Py}-\mathrm{CH}_{2}-\mathrm{O}\right), 6.83$ (s, 9H, Ar, J = 2.2 Hz), 8.01-8.35 (m, $\left.36 \mathrm{H}, \mathrm{H}_{\mathrm{Py}}\right) .{ }^{13} \mathrm{C}-\mathrm{NMR}\left(\mathrm{CDCl}_{3}\right), \delta(\mathrm{ppm}): 45.7\left(\mathrm{Ar}-\mathrm{CH}_{2}-\mathrm{Cl}\right), 68.3\left(\mathrm{Py}_{-} \mathrm{CH}_{2}-\mathrm{O}\right), 101.5\left(\mathrm{C}_{\mathrm{Ar}}\right), 107.4\left(\mathrm{C}_{\mathrm{Ar}}\right)$, $122.4\left(\mathrm{C}_{\mathrm{py}}\right), 124.1\left(\mathrm{C}_{\mathrm{py}}\right), 124.9\left(\mathrm{C}_{\mathrm{py}}\right), 125.6\left(\mathrm{C}_{\mathrm{py}}\right), 126.5\left(\mathrm{C}_{\mathrm{py}}\right), 126.8\left(\mathrm{C}_{\mathrm{py}}\right), 127.1\left(\mathrm{C}_{\mathrm{py}}\right), 127.5\left(\mathrm{C}_{\mathrm{py}}\right)$, $128.9\left(\mathrm{C}_{\mathrm{py}}\right), 130.0\left(\mathrm{C}_{\mathrm{py}}\right), 130.5\left(\mathrm{C}_{\mathrm{py}}\right), 130.9\left(\mathrm{C}_{\mathrm{ipso}} \mathrm{Py}\right), 139.2\left(\mathrm{C}_{\mathrm{ipso}} \mathrm{Ar}\right), 159.6\left(\mathrm{C}_{\mathrm{ipso}} \mathrm{Ar}\right) . \mathrm{MS}(\mathrm{m} / z): 586$ $[\mathrm{M}]^{+}$. Calc. for $\mathrm{C}_{89} \mathrm{H}_{59} \mathrm{ClO}_{6}$ : C, 84.85; H, 4.72 (\%); Found: C, 84.87; H, 4.69 (\%). 
1,1',1", 1'"-((((((((5-(Chloromethyl)-1,3-phenylene)bis(oxy))bis(methylene))bis(benzene-5,3,1-triyl)) tetrakis(oxy))tetrakis(propane-3,1-diyl))tetrakis(oxy)) tetrakis(methylene)) tetrapyrene (13): Yellow powder, yield $4.0 \mathrm{mmol}$ (67\%): FTIR (KBr pellet, $\mathrm{cm}^{-1}$ ): 3206, 3129, 3049, 2937, 2863, 2082, 1970, $1732,1599,1528,1479,1329,1295,1162,1055,845,752,680$. UV-vis $\left(\mathrm{CH}_{2} \mathrm{Cl}_{2}, \mathrm{~nm}\right) \lambda_{\max }: 345,329$, 278, 244. ${ }^{1} \mathrm{H}-\mathrm{NMR}\left(\mathrm{CDCl}_{3}\right) \delta$ (ppm): $2.01\left(\mathrm{~m}, 8 \mathrm{H}, \mathrm{CH}_{2}\right), 3.77\left(\mathrm{~m}, 16 \mathrm{H}, \mathrm{CH}_{2}-\mathrm{O}\right), 4.25\left(\mathrm{~s}, 2 \mathrm{H}, \mathrm{CH}_{2}-\mathrm{Cl}\right)$, 5.16 (s, 4H, $\mathrm{CH}_{2}-\mathrm{O}$ ), 5.20 (s, 8H, Py- $\mathrm{CH}_{2}-\mathrm{O}$ ), 6.21 (br, 3H, Ar), 6.42 (br, 6H, Ar), 7.94-8.33 (m, 36H, Py). ${ }^{13} \mathrm{C}-\mathrm{NMR}\left(\mathrm{CDCl}_{3}\right), \delta(\mathrm{ppm}): 29.4\left(\mathrm{CH}_{2}\right), 46.4\left(\mathrm{CH}_{2}-\mathrm{Cl}\right), 64.6\left(\mathrm{CH}_{2}-\mathrm{O}\right), 66.7\left(\mathrm{CH}_{2}-\mathrm{O}\right), 69.4\left(\mathrm{CH}_{2}-\right.$ O), $71.7\left(\mathrm{Py}_{-} \mathrm{CH}_{2}-\mathrm{O}\right), 100.3\left(\mathrm{HC}_{\mathrm{Ar}}\right), 104.6\left(\mathrm{HC}_{\mathrm{Ar}}\right), 105.3\left(\mathrm{HC}_{\mathrm{Ar}}\right), 105.7\left(\mathrm{HC}_{\mathrm{Ar}}\right), 123.3-129.5\left(\mathrm{C}_{\mathrm{py}}\right)$, $130.5\left(\mathrm{C}_{\mathrm{ipso}}\right), 131.1\left(\mathrm{C}_{\mathrm{ipso}}\right), 131.4\left(\mathrm{C}_{\mathrm{ipso}}\right), 160.2\left(\mathrm{C}_{\mathrm{ipso}}\right)$. MALDI-TOF MS $(\mathrm{m} / \mathrm{z}): 1490(\mathrm{M})$. Calc. for $\mathrm{C}_{101} \mathrm{H}_{83} \mathrm{ClO}_{10}$ : C, 81.30; H, 5.61 (\%); found: C, 81.33; H, $5.60(\%)$.

\subsubsection{General Procedure}

A mixture of compound 8, 9, 12 or compound $13(5.4 \mathrm{mmol})$ and cesium carbonate $(10.1 \mathrm{mmol})$ in DMF (20 mL) was stirred vigorously in nitrogen atmosphere for $30 \mathrm{~min}$. The porphyrin $14(2.7 \mathrm{mmol})$ dissolved in DMF $(10 \mathrm{~mL})$ was added dropwise and the reaction was continued for 3 days. The mixture was filtered. The filtrate was evaporated to dryness under reduced pressure. The organic layer was dried and evaporated to dryness and purified by silica gel chromatography using a mixture of hexane-ethyl acetate 2:1 as an eluent.

Dendrimer 15: Brown powder, yield 0.26 mmol (19\%). FTI. (KBr pellet, $\mathrm{cm}^{-1}$ ): 3313, 3037, 2953, 2869, 1601, 1504, 1467, 1263, 1172, 1007, 842, 800, 707. UV-vis (DMF, nm) $\lambda_{\max }: 329,345,423,518$, 557, 597, 653. ${ }^{1} \mathrm{H}-\mathrm{NMR}\left(\mathrm{CDCl}_{3}\right), \delta(\mathrm{ppm}):-2.18$ (br, 2H, NH), 5.39 (s, 8H, $\left.\mathrm{CH}_{2}-\mathrm{Ar}\right), 5.92(\mathrm{~s}, 16 \mathrm{H}$, $\mathrm{CH}_{2}$-Py), 6.22 (br, 4H, Ar), 6.42 (br, 8H, Ar), 7.79 (d, 8H, Ar, J=8.4 Hz), 7.97-8.43 (m, 72H, Py), 8.62 (d, 8H, Ar, $J=8.4 \mathrm{~Hz}$ ), 8.97 (br, 8H, Porph). ${ }^{13} \mathrm{C}-\mathrm{NMR}$ (THF-d 8 /DMSO-d 6 ), $\delta$ (ppm): 64.4 $\left(\mathrm{CH}_{2}-\mathrm{O}-\mathrm{Ar}\right), 68.5\left(\mathrm{CH}_{2}-\mathrm{O}-\mathrm{Ar}\right), 70.6\left(\mathrm{Py}_{-} \mathrm{CH}_{2}-\mathrm{O}\right), 100.3\left(\mathrm{HC}_{\mathrm{Ar}}\right), 101.6\left(\mathrm{HC}_{\mathrm{Ar}}\right), 105.1(\mathrm{HC} \mathrm{Ar})$, 114.6( $\left.\mathrm{C}_{\text {Ar,porph }}\right), 122.8-130.6\left(\mathrm{C}_{\text {py }}\right), 127.2\left(\mathrm{C}_{\text {pyrrol }}\right), 128.1\left(\mathrm{C}_{\text {Ar,porph }}\right), 131.3\left(\mathrm{C}_{\text {ipso }}\right.$ py $), 131.1\left(\mathrm{C}_{\mathrm{ipso}}\right), 132.4$ $\left(\mathrm{C}_{\mathrm{ipso}}\right), 136.2\left(\mathrm{C}_{\text {Ar,porph }}\right), 138.2\left(\mathrm{C}_{\mathrm{ipso}}\right), 141.5\left(\mathrm{C}_{\text {pyrrol }}\right), 160.6\left(\mathrm{C}_{\mathrm{ipso}}\right)$. MALDI-TOF MS $(\mathrm{m} / \mathrm{z}): 2879\left(\mathrm{M}^{+}\right)$. Calc. for $\mathrm{C}_{208} \mathrm{H}_{134} \mathrm{~N}_{4} \mathrm{O}_{12}$ : C, 86.70; H, 4.69, N 1.94 (\%); found: C, 86.73; H, 4.68 (\%).

Dendrimer 16: Brown powder, yield 0.23 mmol (17\%). FTIR ( $\mathrm{KBr}$ pellet, $\mathrm{cm}^{-1}$ ): 3359, 3194, 2921, 2852, 1730, 1658, 1466, 1271, 1167, 1136, 847, 809, 721. UV-vis (DMF, nm) $\lambda_{\max }: 243,277,328$, 344, 422, 453, 518, 551, 595, 651, 689. ${ }^{1} \mathrm{H}-\mathrm{NMR}\left(\mathrm{CDCl}_{3}\right), \delta$ (ppm): -2.23 (br, 2H, NH), 2.17 (m, 16H, $\mathrm{CH}_{2}$ ), 3.57 (m, 16H, $\left.\mathrm{CH}_{2}-\mathrm{O}\right), 3.79$ (m, 16H, $\mathrm{CH}_{2}-\mathrm{O}$ ), 4.77 (s, 8H, $\mathrm{CH}_{2}-\mathrm{Ar}$ ), 4.98 (s, 16H, $\mathrm{CH}_{2}-\mathrm{Py}$ ), 6.25 (br, 4H, Ar), 6.36 (br, 8H, Ar), 7.56 (d, 8H porph, $J=8.2 \mathrm{~Hz}), 7.74-8.02$ (m, 72H, Py), 8.07 (d, 8H, $\mathrm{Ar}, J=8.2 \mathrm{~Hz}$ ), 8.79 (br, 8H, Ar). ${ }^{13} \mathrm{C}-\mathrm{NMR}$ (THF-d 8 /DMSO-d 6 ), $\delta$ (ppm): 64.8 ( $\left.\mathrm{CH}_{2}-\mathrm{O}-\mathrm{Ar}\right), 68.1$ $\left(\mathrm{CH}_{2}-\mathrm{O}-\mathrm{Ar}\right), 70.9\left(\mathrm{Py}-\mathrm{CH}_{2}-\mathrm{O}\right), 100.4\left(\mathrm{HC}_{\mathrm{Ar}}\right), 101.6\left(\mathrm{HC}_{\mathrm{Ar}}\right), 105.5\left(\mathrm{HC}_{\mathrm{Ar}}\right), 114,3\left(\mathrm{C}_{\mathrm{Ar}, \text { porph }}\right)$, 122.8-130.0 $\left(\mathrm{C}_{\text {py }}\right), 127.2\left(\mathrm{C}_{\text {pyrrol }}\right), 128.5\left(\mathrm{C}_{\text {Ar,porph }}\right), 131.2\left(\mathrm{C}_{\text {ipso }}\right.$ py), $131.3\left(\mathrm{C}_{\mathrm{ipso}}\right), 132.6\left(\mathrm{C}_{\mathrm{ipso}}\right), 136.6$ $\left(\mathrm{C}_{\text {Ar,porph }}\right), 138.3\left(\mathrm{C}_{\mathrm{ipso}}\right), 141.9\left(\mathrm{C}_{\text {pyrrol }}\right), 161.1\left(\mathrm{C}_{\mathrm{ipso}}\right)$. MALDI-TOF MS $(\mathrm{m} / \mathrm{z}): 3343\left(\mathrm{M}^{+}\right)$. Calc. for $\mathrm{C}_{232} \mathrm{H}_{182} \mathrm{~N}_{4} \mathrm{O}_{20}$ : C, 83.28; H, 5.48 (\%); found: C, 83.25; H, 5.43, N 1.67 (\%). 
Dendrimer 17: Black powder, yield $0.11 \mathrm{mmol}(8 \%)$. FTIR (KBr pellet, $\left.\mathrm{cm}^{-1}\right)$ : 3313, 3038, 2923, 1602, 1503, 1470, 1233, 1173, 965, 842, 799, 708. UV-vis (DMF, nm) $\lambda_{\max }: 315,329,345,375,423$, 519, 555, 595, 652. ${ }^{1} \mathrm{H}-\mathrm{NMR}\left(\mathrm{THF}_{-} \mathrm{d}_{8} / \mathrm{DMSO}_{\mathrm{d}}\right.$ ) $\delta$ (ppm): -2.23 (br, 2H, NH), 4.63 (s, 32H, CH$\left.{ }_{2}-\mathrm{Py}\right)$, 5.66 (br, 16H, $\mathrm{CH}_{2}-\mathrm{O}$ ), 5.77 (br, 8H, $\mathrm{CH}_{2}-\mathrm{O}$ ), 6.18 (br, 36H, Ar), 7.67 (d, 8H, Ar, $J=8.6 \mathrm{~Hz}$ ),

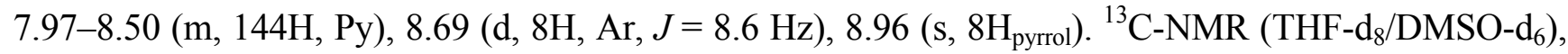
$\delta$ (ppm): $64.6\left(\mathrm{CH}_{2}-\mathrm{O}-\mathrm{Ar}\right), 68.3\left(\mathrm{CH}_{2}-\mathrm{O}-\mathrm{Ar}\right), 70.6\left(\mathrm{Py}-\mathrm{CH}_{2}-\mathrm{O}\right), 100.1\left(\mathrm{HC}_{\mathrm{Ar}}\right), 101.8\left(\mathrm{HC}_{\mathrm{Ar}}\right), 105.0$ $\left(\mathrm{HC}_{\mathrm{Ar}}\right), 114,6\left(\mathrm{C}_{\mathrm{Ar} \text {,porph }}\right), 122.8-130.9\left(\mathrm{C}_{\mathrm{py}}\right), 127.4\left(\mathrm{C}_{\text {pyrrol }}\right), 128.3\left(\mathrm{C}_{\text {Ar,porf }}\right), 131.1\left(\mathrm{C}_{\text {ipso }}\right.$ py $), 131.3\left(\mathrm{C}_{\mathrm{ipso}}\right)$, $132.3\left(\mathrm{C}_{\mathrm{ipso}}\right), 136.8\left(\mathrm{C}_{\text {Ar,porph }}\right), 138.3\left(\mathrm{C}_{\mathrm{ipso}}\right), 141.4\left(\mathrm{C}_{\text {pyrrol }}\right), 160.1\left(\mathrm{C}_{\mathrm{ipso}}\right)$. MALDI-TOF MS $(\mathrm{m} / z): 5567$ $\left(\mathrm{M}^{+}\right)$. Calc. for $\mathrm{C}_{400} \mathrm{H}_{262} \mathrm{~N}_{4} \mathrm{O}_{28}$ : C, 86.22; H, 4.64, N 1.01 (\%); found: C, 86.23; H, 4.62 (\%).

Dendrimer 18: Black powder, yield $0.16 \mathrm{mmol}(12 \%)$. FTIR (KBr pellet, $\left.\mathrm{cm}^{-1}\right): 3312,3039,2925$, 2867, 1901, 1716, 1595, 1460, 1291, 1235, 1164, 1063, 966, 844, 802, 709. UV-vis (DMF, nm) $\lambda_{\max }$ : 244, 278, 329, 345, 423, 455, 519, 557, 594, 652, 693. ${ }^{1} \mathrm{H}-\mathrm{NMR}\left(\mathrm{CDCl}_{3} / \mathrm{CD}_{3} \mathrm{OD}\right) \delta$ (ppm): -2.23 (br, 2H, NH), 1.98 (br, 32H, $\mathrm{CH}_{2}$ ), 3.63 (br, 32H, $\mathrm{CH}_{2}-\mathrm{O}$ ), 3.97 (br, 32H, $\mathrm{CH}_{2}-\mathrm{O}$ ), 4.61 (br, 16H, $\mathrm{CH}_{2}-\mathrm{O}$ ), 4.82 (br, $8 \mathrm{H}, \mathrm{CH}_{2}-\mathrm{O}$ ), 5.17 (br, 32H, $\mathrm{CH}_{2}-\mathrm{Py}$ ), 6.27 (br, 36H, Ar), 7.22 (br, 16H, Ar,), 7.61-8.34 (m, 144H, Py), 8.84 (br, 8H $\left.\mathrm{H}_{\text {pyrrol }}\right) .{ }^{13} \mathrm{C}-\mathrm{NMR}\left(\mathrm{CDCl}_{3} / \mathrm{CD}_{3} \mathrm{OD}\right), \delta(\mathrm{ppm}): 29.5\left(\mathrm{CH}_{2}\right), 60.1\left(\mathrm{CH}_{2}-\mathrm{O}\right), 64.5$ $\left(\mathrm{CH}_{2}-\mathrm{O}\right), 66.5\left(\mathrm{CH}_{2}-\mathrm{O}\right), 68.7\left(\mathrm{CH}_{2}-\mathrm{O}\right), 71.5\left(\mathrm{Py}_{-} \mathrm{CH}_{2}-\mathrm{O}\right), 98.6\left(\mathrm{HC}_{\mathrm{Ar}}\right), 105.8\left(\mathrm{HC}_{\mathrm{Ar}}\right), 107.6\left(\mathrm{HC}_{\mathrm{Ar}}\right)$, $113.1\left(\mathrm{HC}_{\text {Ar,porph }}\right), 119.6\left(\mathrm{C}_{\text {pyrrol }}\right), 123.2-131.1\left(\mathrm{C}_{\text {py }}\right), 135.6\left(\mathrm{C}_{\mathrm{ipso}}\right), 143.4\left(\mathrm{C}_{\text {pyrrol }}\right), 158.6\left(\mathrm{C}_{\mathrm{ipso}}\right), 159.9$ $\left(\mathrm{C}_{\mathrm{ipso}}\right), 160.13\left(\mathrm{C}_{\mathrm{ipso}}\right)$. MALDI-TOF MS $(\mathrm{m} / z)$ : $6496\left(\mathrm{M}^{+}\right)$. Calc. for $\mathrm{C}_{448} \mathrm{H}_{358} \mathrm{~N}_{4} \mathrm{O}_{44}: \mathrm{C}, 86.76 ; \mathrm{H}, 5.55$, N 0.86 (\%); found: C, 86.73; H, 5.57 (\%).

\subsection{Cubic NLO-Characterization}

Finally, some of the synthesized dendrons and dendrimers were also studied as active media for cubic $\chi^{(3)}$-nonlinear optical effects such as nonlinear refraction and absorption via Z-Scan measurements (in spin-coated film samples obtained from THF-based dissolutions). The experimental Z-Scan set-up was implemented using an unpolarized laser beam from a $35 \mathrm{~mW}$ He-Ne laser system working at $632.8 \mathrm{~nm}$ (THORLABS, HRR170-1) [39]. Its energy was carefully monitored and kept constant during long Z-Scan measurements. The spatial mode of the laser beam was close to Gaussian $\mathrm{TEM}_{00}$. The polarization plane of the He-Ne laser beam was adjusted and controlled by means of a linear polarizer mounted on a rotation stage. The polarized laser beam was focused on the sample by means of a positive lens ( $\mathrm{f}=5 \mathrm{~cm}$ ), so that a light power density of $\sim 8.53 \times 106 \mathrm{~W} \mathrm{~m}^{-2}$ reached the studied sample at the focal spot. At last, the samples were mounted on a motorized translation stage ( $25 \mathrm{~mm}$ length travel in steps of $2 \mu \mathrm{m}$ ) in order to perform Z-Scan experiments within the optical focal range. A large area Si-photodetector (EOT ET-2040) was located at $\sim 0.96 \mathrm{~m}$ from the focusing lens, after a $2.5 \mathrm{~mm}$ diameter ( $20 \%$ transmittance) diaphragm-aperture. All NLO-signals captured from photo-detectors were measured with a digital oscilloscope (Tektronix TDS, 744A), and all motion systems and set-up management were automated via a LabView control program.

\section{Conclusions}

Outstanding cubic NLO-effects were particularly measured for the dendrimer-18 based film sample via the Z-Scan technique, where a high NLO-refractive coefficient in the order of $10^{-2}$ esu was found. 
This remarkably NLO-activity is mainly due to the high content of pyrene derivatives available in its respective second generation (dendron 13) building units. In contrast, the first generation dendron 9 and the respective dendrimer-16 compound exhibit lower NLO-activity. Accordingly, film samples obtained from compounds $\mathbf{1 3}$ and $\mathbf{1 8}$ consistently exhibited TPA-NLO absorption effects at same experimental conditions. However, more NLO-investigations should be performed in these materials in order to further understand the electronic and thermal contributions to the cubic nonlinearities.

\section{Acknowledgments}

This work was supported by the DGAPA (IN202010). We would also like to thank Rios O.H., Velasco L., Huerta S.E., Patiño M.M.R., Rodriguez-Rosales A.A. and Peña Gonzalez M.A., for technical assistance.

\section{Conflict of Interest}

The authors declare no conflict of interest.

\section{References}

1. Zeng, F.; Zimmerman, S.C. Dendrimers in supramolecular chemistry: From molecular recognition to self-assembly. Chem. Rev. 1997, 97, 1681-1712.

2. Newkome, G.R.; He, E.; Moorefield, C.N. Suprasupermolecules with novel properties: Metallodendrimers. Chem. Rev. 1999, 99, 1689-1746.

3. Smith, D.K.; Diederich, F. Supramolecular dendrimer chemistry: A journey through the branched architecture. Top. Curr. Chem. 2000, 210, 183-227.

4. Emrick, T.; Fréchet, J.M.J. Self-assembly of dendritic structures. Curr. Opin. Colloid Interf. Sci. 1999, 4, 15-23.

5. Bosman, A.W.; Janssen, H.M.; Meijer, E.W. About dendrimers: Structure, physical properties, and applications. Chem. Rev. 1999, 99, 1665-1688.

6. Dendrimers and other Dendritic Polymers; Fréchet, J.M.J., Tomalia, D.A. Eds.; Wiley: Chichester, UK, 2001.

7. Newkome, G.R.; Moorefield, C.N.; Vögtle, F. Dendrimers and Dendrons: Concepts, Syntheses, Applications; Wiley-VCH: Weinheim, Germany, 2001.

8. Vögtle, F.; Richardt, G.; Werner, N. Dendrimer Chemistry: Concepts, Syntheses, Properties, Applications; Wiley-VCH, Weinheim, Germany, 2009.

9. Valerio, C.; Fillaut, J.L.; Ruiz, J.; Guittard, J.; Blais, J.C.; Astruc, D. The Dendritic effect in molecular recognition: Ferrocene dendrimers and their use as supramolecular redox sensors for the recognition of small inorganic anions. J. Am. Chem. Soc. 1997, 119, 2588-2589.

10. Valerio, C.; Alonso, E.; Ruiz, J.; Blais, J.C.; Astruc, D. A polycationic metallodendrimer with 24 $\left[\mathrm{Fe}\left(\eta^{5}-\mathrm{C}_{5} \mathrm{Me}_{5}\right)\left(\eta^{6}-N \text {-Alkylaniline }\right)\right]^{+}$termini that recognizes chloride and bromide anions. Angew. Chem. Int. Ed. 1999, 38, 1747-1751.

11. Labande, A.; Astruc, D. Colloids as redox sensors: Recognition of $\mathrm{H}_{2} \mathrm{PO}_{4}{ }^{-}$and $\mathrm{HSO}_{4}{ }^{-}$by amidoferrocenylalkylthiol-gold nanoparticles. Chem. Commun. 2000, 1007-1008. 
12. Nlate, S.; Ruiz, J.; Sartor, V.; Navarro, R.; Blais, J.C.; Astruc, D. Molecular batteries: Ferrocenylsilylation of dendrons, dendritic cores, and dendrimers: New convergent and divergent routes to ferrocenyl dendrimers with stable redox activity. Chem. Eur. J. 2000, 6, 2544-2553.

13. Labande, A.; Ruiz, J.; Astruc, D. Supramolecular gold nanoparticles for the redox recognition of oxoanions: Syntheses, titrations, stereoelectronic effects, and selectivity. J. Am. Chem. Soc. 2002, 124, 1782-1789.

14. Tomalia, D.A.; Naylor, A.M.; Goddard, W.A., III. Starburst dendrimers: Molecular-level control of size, shape, surface chemistry, topology, and flexibility from atoms to macroscopic matter. Angew. Chem. Int. Ed. 1990, 29, 138-175.

15. Ornelas, C.; Ruiz, A.J.; Cloutet, E.; Alves, S.; Astruc, D. Click assembly of 1,2,3-triazole-linked dendrimers, including ferrocenyl dendrimers, which sense both oxo anions and metal cations. Angwe. Chem. Int. Ed. 2007, 46, 872-877.

16. Goodson, T., III; Varnavski, O.; Wang, Y. Optical properties and applications of dendrimer-metal nanocomposites. Int. Rev. Phys. Chem. 2004, 23, 109-150.

17. Wang, W.; Sun, H.; Kaifer, E.A. Redox active, hybrid dendrimers containing Fréchet- and Newkome-type blocks. Org. Lett. 2007, 9, 2657-2660.

18. Ispasoiu, R.G.; Balogh, L.; Varnavski, O.P.; Tomalia, D.A.; Goodson, T., III. Large optical limiting from novel metal-dendrimer nanocomposite materials. J. Am. Chem. Soc. 2000, 122, 11005-11006.

19. Samoc, M.; Samoc, A.; Luther-Davies, B.; Humphrey, M.G.; Wong, M.S. Third-order optical nonlinearities of oligomers, dendrimers and polymers derived from solution Z-scan studies. Opt. Mater. 2003, 21, 485-488.

20. Astruc, D.; Boisselier, E.; Ornelas, C. Dendrimers designed for functions: From physical, photophysical, and supramolecular properties to applications in sensing, catalysis, molecular electronics, photonics, and nanomedicine. Chem. Rev. 2010, 110, 1857-1959.

21. Boas, U.; Christensen, J.B.; Heegaard, P.M.H. Dendrimers in Medicine and Biotechnology: New Molecular Tools; RSC Publishing: Cambridge, UK, 2006.

22. Mintzer, M.A.; Grinstaff, M.W. Biomedical applications of dendrimers: A tutorial. Chem. Soc. Rev. 2011, 40, 173-190.

23. Cameron, D.J.A.; Shaver, M.P. Aliphatic polyester polymer stars: Synthesis, properties and applications in biomedicine and nanotechnology. Chem. Soc. Rev. 2011, 40, 1761-1776.

24. Powell, C.E.; Hurst, S.K.; Morrall, J.P.; Cifuentes, M.P.; Roberts, R.L.; Samoc, M.; Humphrey, M.G. Organometallic complexes for nonlinear optics. 39. Syntheses and third-order nonlinear optical properties of first-generation peripherally metalated arylalkynyl dendrimers. Organometallics 2007, 26, 4456-5576.

25. Majoral, J.P. State of the art developments in the chemistry and properties of dendrimers and hyperbranched polymers. New J. Chem. 2007, 31, 1039-1040.

26. Al-Jamal, K.T.; Ramaswamy, C.; Florence, A.T. Supramolecular structures from dendrons and dendrimers. Adv. Drug Deliv. Rev. 2005, 57, 2238-2270.

27. Röglin, L.; Lempens, E.H.M.; Meijer, E.W. A synthetic "tour de force": Well-defined multivalent and multimodal dendritic structures for biomedical applications. Angew. Chem. Int. Ed. 2011, 50, 102-112. 
28. Cifuentes, M.P.; Powell, C.E.; Morrall, J.P. Electrochemical, spectroelectrochemical, and molecular quadratic and cubic nonlinear optical properties of alkynylruthenium dendrimers. J. Am. Chem. Soc. 2006, 128, 10819-10832.

29. Kraft, A.; Grimsdale, A.C.; Holmes, A.B. Electroluminescent conjugated polymers-seeing polymers in a new light. Angew. Chem. Int. Ed. 1998, 37, 402-428.

30. Lo, S.-C.; Burn, P.L. Development of dendrimers: Macromolecules for use in organic light-emitting diodes and solar cells. Chem. Rev. 2007, 107, 1097-1116.

31. Burn, P.L.; Lo, S.-C.; Samuel, I.D.W. Metallo-supramolecular block copolymers. Adv. Mater. 2007, 19, 1675-1688.

32. Hawker, C.J.; Fréchet, J.M.J. Preparation of polymers with controlled molecular architecture. A new convergent approach to dendritic macromolecules. J. Am. Chem. Soc. 1990, 112, 7638-7648.

33. Sheik-Bahae, M.; Said, A.A.; van Stryland, E.W. High-sensitivity, single-beam $\mathrm{n}_{2}$ measurements. Opt. Lett. 1989, 14, 955-957.

34. Sheik-Bahae, M.; Said, A.A.; Hagan, D.J.; Soileau, M.J.; van Stryland, E.W. Nonlinear refraction and optical limiting in "thick" media. Opt. Eng. 1991, 30, 1228-1235.

35. Sheik-Bahae, M.; Said, A.A.; Wei, T.-H.; Hagan, D.J.; van Stryland, E.W. Sensitive measurement of optical nonlinearities using a single beam. IEEE J. Quantum Electron. 1990, 26, 760-769.

36. Xia, T.; Hagan, D.J.; Sheik-Bahae, M.; van Stryland, E.W. Eclipsing Z-scan measurement of $\lambda / 10^{4}$ wave-front distortion. Opt. Lett. 1994, 19, 317-319.

37. Nonlinear Optics of Organic Molecules and Polymers; Nalwa, H.S., Miyata S., Eds.; CRS Press Inc.: Boca Raton, FL, USA, 1997.

38. Liu, X.; Guo, S.; Wang, H.; Hou, L. Theoretical study on the closed-aperture Z-scan curves in the materials with nonlinear refraction and strong nonlinear absorption. Opt. Commun. 2001, 197, 431-437.

39. Rodríguez-Rosales, A.A.; Morales-Saavedra, O.G.; Román, C.J.; Ortega-Martínez, R. Variation of nonlinear refractive index in dye-doped liquid crystals by local and nonlocal mechanisms. Opt. Mater. 2008, 31, 350-360.

Sample Availability: Not available

(C) 2011 by the authors; licensee MDPI, Basel, Switzerland. This article is an open access article distributed under the terms and conditions of the Creative Commons Attribution license (http://creativecommons.org/licenses/by/3.0/). 